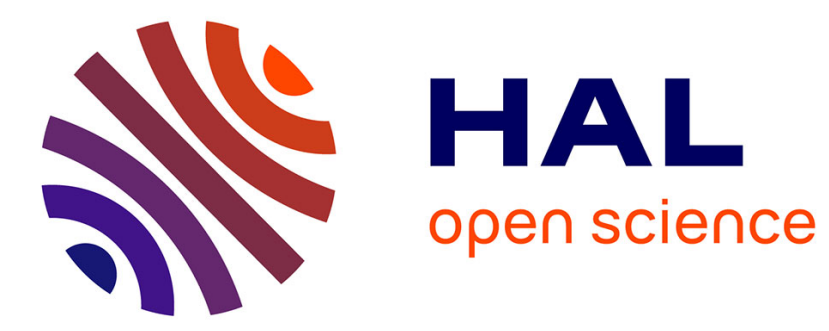

\title{
Evidence for ancient lithospheric deformation in the East European Craton based on mantle seismic anisotropy and crustal magnetics
}

\author{
Andreas Wuestefeld, Goetz Bokelmann, Guilhem Barruol
}

\section{To cite this version:}

Andreas Wuestefeld, Goetz Bokelmann, Guilhem Barruol. Evidence for ancient lithospheric deformation in the East European Craton based on mantle seismic anisotropy and crustal magnetics. Tectonophysics, 2010, 481 (1-4), pp.16-28. 10.1016/j.tecto.2009.01.010 . hal-00475647

\section{HAL Id: hal-00475647 \\ https://hal.science/hal-00475647}

Submitted on 27 Oct 2016

HAL is a multi-disciplinary open access archive for the deposit and dissemination of scientific research documents, whether they are published or not. The documents may come from teaching and research institutions in France or abroad, or from public or private research centers.
L'archive ouverte pluridisciplinaire HAL, est destinée au dépôt et à la diffusion de documents scientifiques de niveau recherche, publiés ou non, émanant des établissements d'enseignement et de recherche français ou étrangers, des laboratoires publics ou privés. 


\title{
Evidence for ancient lithospheric deformation in the East European Craton based on mantle seismic anisotropy and crustal magnetics
}

\author{
Andreas Wüstefeld ${ }^{*, 1}$, Götz Bokelmann ${ }^{2}$, Guilhem Barruol ${ }^{2}$ \\ Université Montpellier II, CNRS, Geosciences Montpellier, 34095 Montpellier, France
}

\section{A R T I C L E I N F O}

Article history:

Received 28 May 2008

Accepted 6 January 2009

Available online 19 January 2009

Keywords:

Lithosphere

Asthenosphere

Craton

Anisotropy

Shear-wave splitting

East Europe

\begin{abstract}
A B S T R A C T
We present new shear wave splitting measurements performed at 16 stations on the East European Craton, and discuss their implications in terms of upper mantle anisotropy for this geophysically poorly known region. Previous investigations of mantle anisotropy in Central Europe have shown fast directions aligning smoothly with the craton's margin and various suggestions have been proposed to explain their origin such as asthenospheric flow or lithospheric frozen in deformation.

Here, we aim at investigating the continuation of this shear wave splitting pattern further to the East, into the East European Craton. For the craton, the interpretation appears to be less ambiguous than for central Europe since several arguments support lithospheric anisotropy in this region: 1) The large scale coherence within either of the four constituting blocks and the significant variations between the blocks on a small scale, 2) the weak correlation with absolute plate motion vectors, and 3) the good correlation between anisotropy and crustal features, for which we use magnetic field alignments as a proxy. Rather good correlation of these magnetic features with seismic fast orientations strongly supports the idea of vertically coherent deformation throughout upper mantle and crust. The observed splitting orientations thus reflect the last tectonic events of each block, frozen in into the lithosphere for hundreds of millions of years.
\end{abstract}

\section{Introduction}

Deformation in the Earth's mantle can be constrained by seismic anisotropy, which is caused by deformation induced alignment of anisotropic minerals, especially olivine, into "crystal preferred orienta tions" (CPO) (Nicolas and Christensen, 1987; Tommasi, 1998; Ben Ismaïl and Mainprice, 1998; Mainprice et al., 2000). A change in stress regime (and thus deformation) may erase any existing CPO relatively quickly by developing new fabric or by recrystallisation processes (Nicolas et al., 1973; Mainprice and Silver, 1993). Therefore, any anisotropy in the lithosphere can be assumed to reflect the last period of significant deformation, or the last thermal event. In stable tectonic regimes, the anisotropy caused by the last period of deformation may remain "frozen" in the lithospheric rocks during post tectonic thermal relaxa tion (Vauchez and Nicolas, 1991; James and Assumpcao, 1996; Barruol et al., 1997, 1998; Heintz and Kennett, 2006).

Seismic anisotropy can be detected with a broad range of seismic waves: Surface waves (e.g., Montagner, 1986), P waves (e.g., Babuška and Cara, 1991; Bokelmann, 1995; Bear et al., 1999; Schulte Pelkum et al., 2001; Bokelmann, 2002a), by means of Receiver Functions (Levin and Park, 1997) and particularly by using the splitting of shear

\footnotetext{
* Corresponding author. Fax: +44 1179253385.

E-mail address: andy.wuestefeld@bristol.ac.uk (A. Wüstefeld).

1 Now at: Department of Earth Sciences, University of Bristol, UK.

2 Fax: +441179253385.
}

waves (Fukao, 1984; for reviews see Silver, 1996; Savage, 1999), which uses the birefringence of seismic shear waves: When passing through an anisotropic medium, a shear wave is split into two separate waves that are polarized along the anisotropic symmetry axes and travel at different speeds. That velocity difference leads to a delay between the arrival times of the two waves, which is proportional to the length of the travel path in the anisotropic layer and the strength of the anisotropy. Shear wave splitting techniques generally try to reverse the splitting effect by grid searching over all possible anisotropy orientations and delay times. The best removal of the splitting is based on different criteria, such as cross correlation of fast and slow wave (Bowman and Ando, 1987), eigenvalue criteria (Silver and Chan, 1988), or minimal energy on the transverse component (Silver and Chan, 1991). The method proposed by Chevrot (2000), on the other hand, uses the backazimuthal variation of splitting strength as indicator for anisotropic orientation and strength. These methods are compared by Long and van der Hilst (2005), Evans et al. (2006), and Wüstefeld and Bokelmann (2007). For backazimuthal variations of splitting and 3D modeling of fabrics see Sileny and Plomerova (1996).

Over the past two decades the method of shear wave splitting has been widely applied in several active tectonic settings: Subduction zones (e.g., Margheriti et al., 2003; Levin et al., 2004; Nakajima and Hasegawa, 2004; Plomerová et al., 2006), rifts (Kendall, 1994; Gao et al., 1997; Vauchez et al., 1999; Walker et al., 2004; Kendall et al., 2005), hotspots (Walker et al., 2001; Barruol and Granet, 2002; 
Walker et al., 2005), oceanic islands (Behn et al., 2004; Fontaine et al., 2005, 2007), orogens (e.g., Barruol et al., 1998; Flesch et al., 2005).

In contrast to those active zones, cratons constitute the old, stable parts of continents. Studies of cratonic areas include North America (e.g., Silver and Kaneshima, 1993; Barruol et al., 1997; Bokelmann and Silver, 2000; Fouch et al., 2000; Snyder et al., 2003), Kaapvaal craton (Vinnik et al., 1996, Silver et al., 2001; Gao et al., 2002) South American Craton (Heintz et al., 2003; Assumpção et al., 2006), Australian shield (Heintz and Kennett, 2005, 2006). See Fouch and Rondenay, 2006 for a review. The information on upper mantle deformation that they supply is particularly valuable for cratonic regions, since other observational constraints on depth, such as lithospheric flexure, are lacking there. The particularity of cratonic regions is that they are generally associated with thick lithospheric roots that move coherently with the plates. The surrounding of lithospheric roots can deform more easily than the stable, thicker and colder inner parts. This raises the question of how mantle deformation due to the relative motion between surface plate and deeper mantle is accommodated. The thick lithospheric roots are also thought to act as keels that could deviate mantle flow around them (McKenzie, 1979; Bormann et al., 1993; Fouch et al., 2000). Seismic anisotropy in such environments may help to distinguish present day deformation at depth, associated with plate motion (McKenzie, 1979), from fossil deformation (e.g., Bokelmann and Silver, 2002; Vecsey et al., 2007). In this study, we focus on anisotropy beneath the East European Craton (EEC).

Fig. 1 shows shear wave splitting measurements from 28 studies available in Central Europe. Relevant references are given below in the corresponding sections. The data are taken from the interactive shear wave splitting database (Wüstefeld et al., submitted for publication; http://www.gm.univ montp2.fr/splitting/DB/), which is a freely accessible repository of teleseismic shear wave splitting publications. Researchers are invited to add their results to provide a comprehen sive, up to date database. Although shear wave splitting has been investigated around the EEC in detail, the anisotropy of the craton itself is poorly known. In Central Europe, shear wave splitting observations show orientations of the fast shear wave polarization plane $\Phi$ sub parallel to the edge of the craton. They may thus indicate an asthenospheric mantle flow deflected by the craton's edge at depth (Bormann et al., 1993). However, these directions are also close to the trend of the Hercynian fold belt in Central Europe, which might on the other hand suggest, that the anisotropy is frozen into the subcrustal lithosphere (e.g., Babuška et al., 1993; Plomerová et al., 1998; Brechner et al., 1998; Plenefisch et al., 2001; Babuška and Plomerová, 2006). The debate on the nature of the anisotropy in Central Europe is not completely resolved. Perhaps additional data will help (e.g., Walther et al., 2007). If one could determine the sense of shear at depth from anisotropy observations, this question might be resolved (e.g. Bokelmann, 2002a). On the other hand, the depth extent of anisotropy would be indicative as well (Montagner, 1998; Mainprice et al., 2000; Kendall, 2000), but shear wave splitting gives only relatively weak constraints on depth. Sieminski et al. (2007) showed that SKS shear wave splitting is mostly sensitive to anisotropy in the upper mantle. The depth at which splitting occurs can be further constrained by comparing observations from different azimuths, and at different stations (Silver and Savage, 1994; Rümpker and Silver, 1998; Saltzer et al., 2000), although this approach assumes horizontal symmetry axes of anisotropy. We may also resort to surface waves which have better vertical resolution, but weaker lateral resolution.

Studying seismic anisotropy in cratonic regions gives an interest ing opportunity to analyze deformation processes in the mantle and to address the following geodynamics questions, amongst others:

- How did the lithosphere develop and deform?

- Is the whole lithosphere affected by the deformation, or only part of the keel (in the case of lithospheric anisotropy)?

- Is there evidence for multi layer (e.g., lithospheric plus astheno spheric) anisotropy?

- How is mantle flow affected by a deep and more resistant lithospheric root?

- How does the topography at the base of the craton affect mantle flow?

- How and to what extent do abandoned rifts affect the splitting measurements in Eastern Europe?

In recent years, there has been growing interest in studying the geodynamics of the stable portion of Europe (e.g., Bogdanova, 1996;

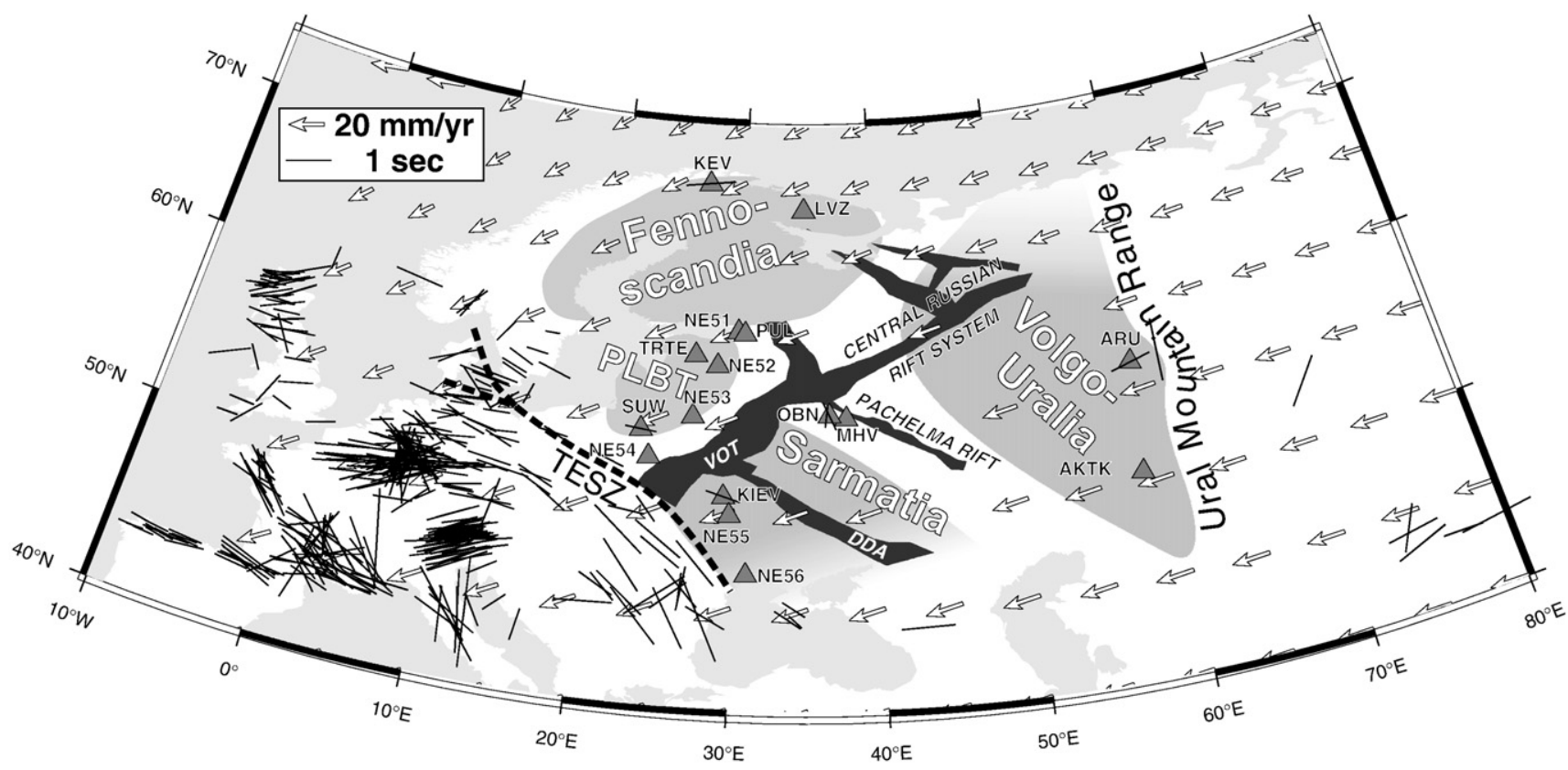

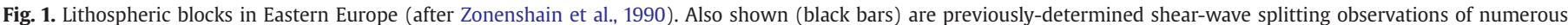

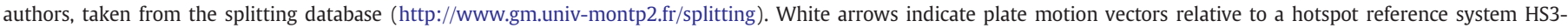

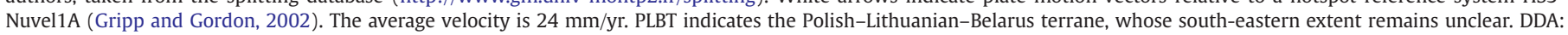
Dnieper-Donets Aulacogen, VOT: Volhyn-Orsha Trough. The gray triangles represent the stations included in this study. 
Grad et al., 2003; Bruneton et al., 2004; Bogdanova et al., 2006; Pedersen et al., 2006; Vecsey et al., 2007; Artemieva, 2007). However, only a few of the available seismological stations on the EEC have been analysed so far in terms of mantle anisotropy (e.g., Silver and Chan, 1991; Makeyeva et al., 1992; Helffrich et al., 1994; Dricker et al., 1999), and the craton has not yet been discussed as a whole, motivating this study of the anisotropy and deformation of the EEC.

\section{Geology of the East European Craton}

The ancient core of Europe is composed of three major crustal segments: Fennoscandia, Sarmatia and Volgo Uralia (Fig. 1). The EEC is today mostly covered by Phanerozoic sediments. Only the north west (Fennoscandian Shield) and parts in the south (Ukrainian Shield and Voronezh Massif) display Proterozoic and Archean rocks (Gorbatschev and Bogdanova, 1993; Bogdanova et al., 1996).

Between 2.1 and $2.0 \mathrm{Ga}$ the oceanic domain, which separated Sarmatia from Volgo Uralia, closed. Simultaneously, subduction started in the (present day) northern edge of Sarmatia and lead to the collision with Fennoscandia at around $1.8 \mathrm{Ga}$. The accretion of the two blocks was completed at around $1.75 \mathrm{Ga}$. The central part of Fennoscandia remained stable for at least $1.2 \mathrm{Ga}$. The Sarmatian block is a stable Archean Craton, created by late Archean / early Palaeopro terozoic welding of several terranes with different ages ranging from 3.8 to $2.8 \mathrm{Ga}$ (Shcherback, 1991). The Archean crust of Volgo Uralia underwent apparently reorganization into a system of dome like structures (Bogdanova, 1996).

The Central Russian Rift Systems is a consequence of successive rifting episodes during (1.25 $0.8 \mathrm{Ga}$ ) the assemblage of Fennoscandia, Sarmatia and Volgo Uralia. The riftings occurred mainly along the old suture zones (Bogdanova, 1996). A suite of small failed arm rifts accompany the major rifts, namely: The late Riphean Volhyn Orsha trough divides Fennoscandia from Sarmatia and shows purely extensional features. In contrast, the Central Russian rift system is ca. $250 \mathrm{~km}$ wide and comprises a series of en echelon troughs. Finally, the Pachelma rift system is offset by ca $150 \mathrm{~km}$ to the northwest of the surface trace of the suture. Bogdanova et al. (2006) suggest that during that period Volgo Uralia acted as a wedge between Fennos candia and Sarmatia. As such Volgo Uralia moved to the present day west, while Fennoscandia escaped to the present day north.

The Trans European suture zone (TESZ) marks the contact between the Precambrian East European Craton and the Phanerozoic collage of central Europe terranes. It is a broad, complex zone resulting from the collision of continental blocks which lasted until the Variscan orogeny (Ziegler, 1990; Berthelsen, 1992; Pharaoh et al., 1997; Grad et al., 2003). In its southern portion, the TESZ roughly corresponds to an upper mantle transition from the high ( $\mathrm{S}$ wave) velocity EEC to lower velocities beneath the younger terranes to the west (Zielhuis and Nolet, 1994). Furthermore, Babuška et al. (1998) found different anisotropic structure on either side of the TESZ.

The Ural Mountains are the topographic and tectonic feature separating Europe from Asia and therefore represent the eastern boundary of the EEC. The carboniferous (ca. $350 \mathrm{Ma}$ ) closure of the Ural paleo ocean accreted the East European Craton to the Siberian Craton, while the convergence continued into early Triassic ( $250 \mathrm{Ma})$. The Urals extend in North South direction more than $2500 \mathrm{~km}$, from the Aral Sea to the Arctic Ocean. The final subduction was directed towards the present day east (Perez Estaun and Brown, 1996). The eastern flank is a mosaic of accreted terranes and obducted slabs (Brown et al., 1996).

As a fourth constituent of the EEC, Bogdanova (2005, and papers therein) points out the evidence for a terrane in the area NE of the TESZ and Fennoscandia, comprising NE Poland, parts of Belarus and the Baltic states. According to Bogdanova (2005) geophysical data and drillcore materials in this area identify several independent tectonic blocks between Fennoscandia and Sarmatia (Fig. 1). Some features continue through NE Poland all the way to the TESZ. The evolutionary histories of these belts allow for grouping them into three different subterranes though tectonic reconstruction and age determination remains imprecise.

\section{Geophysical characteristics of the EEC}

\subsection{Tomography}

Surface wave tomography provides the unique possibility to coherently study the lithospheric structure of the vast area covered by the EEC and to provide images of upper mantle structures, such as the presence of high velocity areas that may constrain the thickness of the lithosphere. Fig. 2 shows the EEC as seen in the global model of Debayle et al. (2005). The EEC can be well identified as a region of faster than average material down to depths well below $200 \mathrm{~km}$. This high velocity body extends from the Urals to the TESZ and from the Arctic Sea and Finland towards the Black Sea. Note the thinner than average lithosphere beneath Sarmatia. The other constituting blocks cannot be identified in surface wave topographic models. This is probably due to the resolution of the method and the low ray coverage in this region.

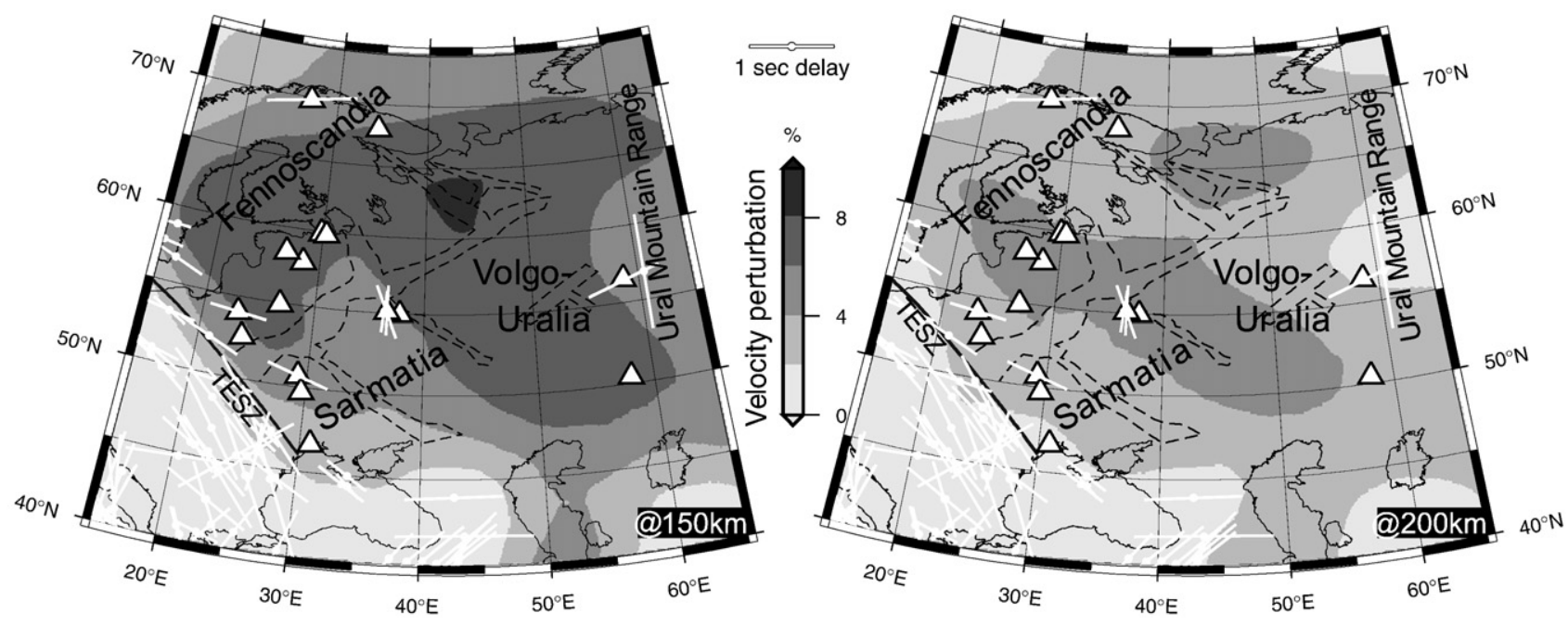

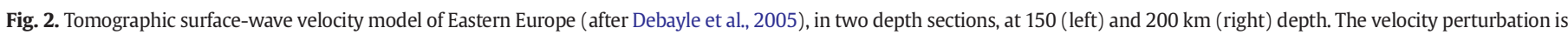

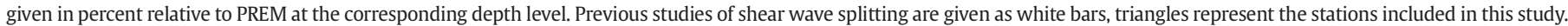




\subsection{Present day motion of the EEC}

Fig. 1 shows the present day plate motion according to the hot spot reference frame model HS3 (Gripp and Gordon, 2002). The previously available results from Central Europe are in good alignment with absolute motion and shear wave splitting only for a few places. Close to the boundary of the craton, fast orientations clearly deviate from plate motion direction and become tangential to the craton edge. This might be an effect of mantle flow deviated by the thick lithosphere of the EEC. On the other hand, this pattern also follows the general Hercynian structures, which alternatively might indicate lithospheric origins of anisotropy. Quantifying the motion of the plates is a key point in discussing and interpreting upper mantle anisotropy measurements since part of the signal may be acquired in the asthenosphere, due to plate drag. In that case, minerals should align parallel to the direction of the relative motion between moving plate and underlying mantle (Nicolas and Christensen, 1987). This effect is expected to be independent of plate velocity. Slow moving plates would simply require a longer time of uniform plate motion to align the minerals. This 'simple asthenospheric flow' model (Vinnik et al., 1984; Bormann et al., 1993; Silver, 1996) predicts that anisotropic orientations should be parallel to the absolute plate motion direction, assuming that mantle convection is much slower than plate motions.

Plate kinematic models describe the velocities of points at the Earth's surface due to plate tectonic motions. These absolute plate motion vectors (APM) are either derived from (a) geodetic space techniques such as VLBI, SLR and GPS (e.g. Drewes, 1998; Sella et al., 2002), or from (b) geophysical observations such as sea floor spreading rates, transform fault and earthquake slip azimuths (e.g., Gripp and Gordon, 1990; Argus and Gordon, 1991; DeMets et al., 1994; Gripp and Gordon, 2002; Kreemer et al., 2003). Hotspots have been thought to be the surface manifestation of deep mantle plumes (Morgan, 1971) but it remains a matter of debate if the hotspots can be assumed as stationary (Steinberger and OConnel, 1998; Tarduno et al., 2003; Andrews et al., 2006). Nevertheless, the hotspot frame remains the appropriate choice for geodynamic interpretations. The direction of HS3 plate motion vectors in Europe bend from W in the Urals to SW in the Iberian Peninsula.

All of the above mentioned models agree that the APM velocity of Europe is relatively slow. No Net Rotation (NNR) solutions give an average velocity of $25 \mathrm{~mm} / \mathrm{yr}$ and $24.6 \mathrm{~mm} / \mathrm{yr}$ for the REVEL2000 (Sella et al., 2002) and APKIM2000 (Drewes, 1998) models, respectively. In the older hotspot reference frame model HS2 Nuvel1A (Gripp and Gordon, 1990), average APM is $10.6 \mathrm{~mm} / \mathrm{yr}$. This is half the velocity of the latest model, HS3 Nuvel1A, which results in $20 \mathrm{~mm} / \mathrm{yr}$. However, the directions of the NNR and hotspot reference frames result in opposite directions of plate motion for Europe. In the NNR, Europe moves generally towards NE and E, while in a hotspot frame this motion is SW to west. We will later in this study compare the splitting observations with the different plate motion models.

\subsection{Magnetic anomalies}

Fig. 3 shows the residual magnetic field at an altitude of $5 \mathrm{~km}$ based on a recent compilation of global magnetic data (Korhonen et al.,

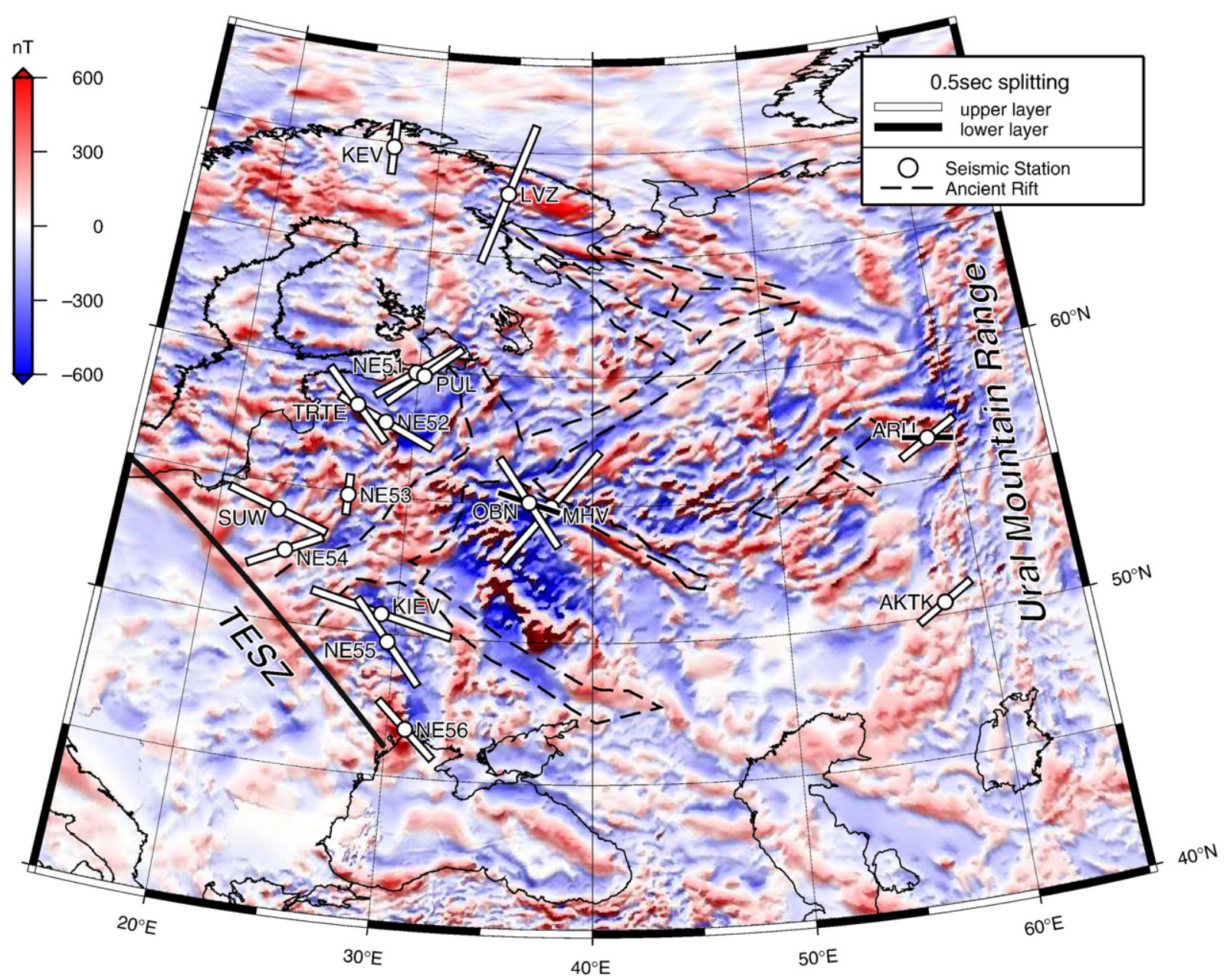

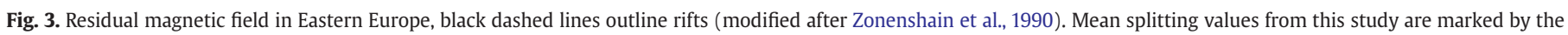
white bars. At stations where two layers have been detected, the white bar corresponds to the upper layer and the black bar to the lower layer. 


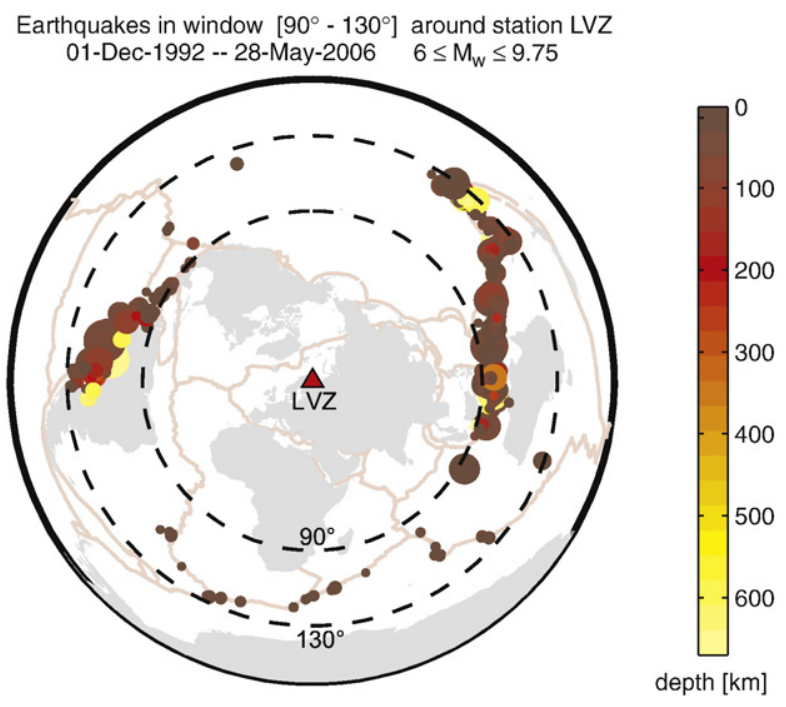

Fig. 4. Earthquake data distribution for splitting analysis, shown for station LVZ on the Kola Peninsula (epicentral distance between 90 and 130 degrees). The event locations are given by circles whose sizes indicate event magnitude $\left(M_{\mathrm{W}}\right)$. Shading represents the epicentral depth.
2007). Some geological features, such as the Pachelma Rift, are well represented as lineaments with short scale variations. Linear features also mark the Polish Lithuanian Belarus terrane, curving from NNE SSW in the south to E W directions in the northern part of the terrane. The Ural Mountains show patches of positive anomalies largely aligning parallel to the trend of the belt. The boundary between the EEC and Urals is sharply defined as a negative magnetic anomaly. At $58^{\circ} \mathrm{N}$ latitude, just north of station ARU, a lineament of alternating positive and negative anomalies is $\mathrm{E}$ W oriented.

For the shield region, it shows frequently a 'checkerboard pattern' of magnetic intensity. A zone of intense non segmented positive field can be distinguished in the central part of the Kola Peninsula, close to station LVZ. The central part of the Russian platform can be characterized by a complex structure of the magnetic field, by a combination of systems of checkerboard field with various orienta tions, and linear anomalies. Sections of the magnetic field correspond ing to the Ukrainian Shield, and Voronezh Massif, amongst others, can be distinguished within its limits. However, these limits do not always coincide with their surface expression (Zonenshain et al., 1990). The magnetic field of the Ukrainian shield can be characterized by great differentiation, by the presence of an anomalous zone with steep horizontal gradients, sometimes as much as $10 \mu \mathrm{T} / \mathrm{km}$.

Magnetic anomalies represent structural and/or compositional differences at depths where temperatures are below the Curie
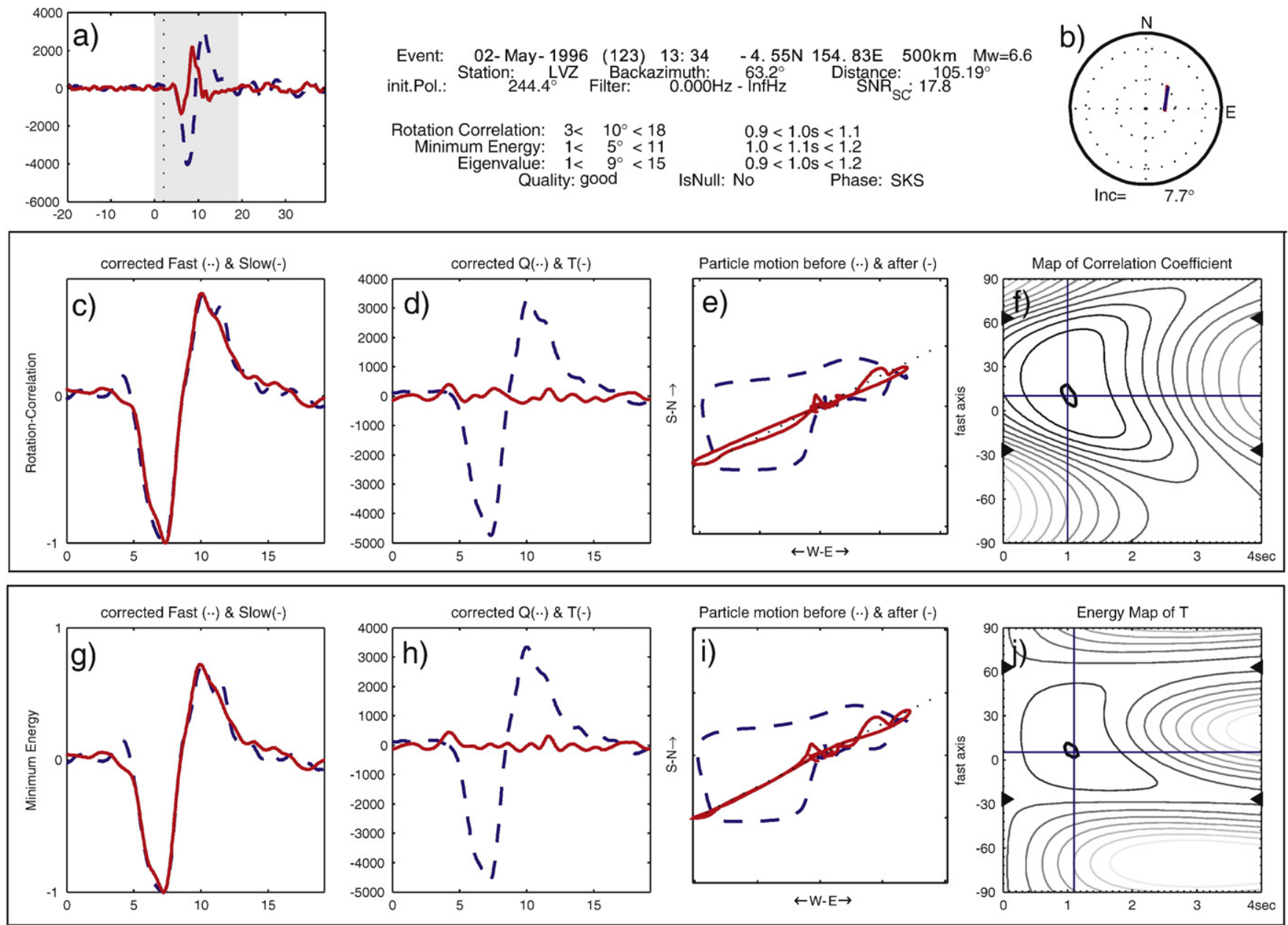

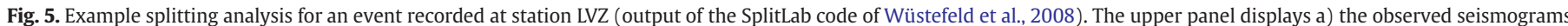

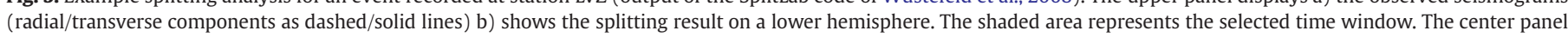

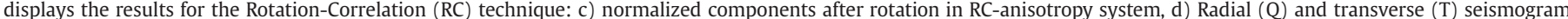

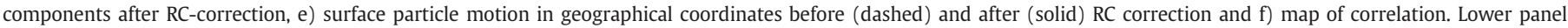

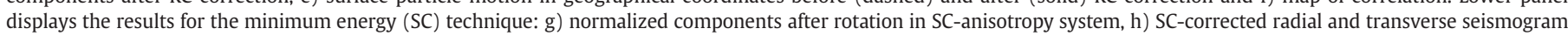
component, i) SC particle motion before and after correction and j) map of minimum energy on transverse component. 
Temperature. At higher temperatures, the magnetization of the material is lost. For rock magnetism, the most important mineral is magnetite $\left(\mathrm{Fe}_{3} \mathrm{O}_{4}\right)$ which has a Curie temperature of $578{ }^{\circ} \mathrm{C}$. Depending on the geothermal gradient, this temperature is reached in the Earth at depth as shallow as $15 \mathrm{~km}$ at mid ocean ridges and $30 \mathrm{~km}$ for continents (e.g., Turcotte and Schubert, 2002). In cratonic regions, the Curie isotherm can be significantly deeper and may reach depths of $70 \mathrm{~km}$ (e.g., Artemieva, 2006). Furthermore, the magnetic intensity is strongly distance dependant. Therefore, the observed magnetic anomalies represent essentially only crustal features. This renders magnetic data particularly interesting to us, since they might give constraints on crustal structure and fabric. We are particularly interested in magnetic lineaments, for developing a proxy for crustal fabric, which is otherwise difficult to obtain for the EEC, since much of surface extent is covered by sediments. Fabric of the subsedimentary basement is therefore hardly known so far.

The comparison of magnetic lineaments with anisotropic $\Phi$ can thus yield valuable information of crust mantle interaction (Bokelmann and Wüstefeld, 2009). In particular, parallelism of these two indepen dent datasets allows addressing the question whether deformation in crust and lithosphere is vertically coherent (VCD, cf. Silver, 1996).

\section{Seismic anisotropy: data origin and processing}

The EEC is covered by a number of permanent broad band seismographs, maintained by several networks. Figs. 1 and 3 give an overview of the 16 stations analysed in this study. The stations are distributed irregularly over the area. However, they cover all major geologic regions of the EEC. The data quality is also variable, where the best signal to noise ratios (SNR) were found at stations KEV and ARU.
Unfortunately, the NARS network stations (Muyzert et al., 1999) provided only few events for shear wave splitting measurements.

Most of the events used for shear wave splitting analysis have backazimuth between $45^{\circ}$ and $100^{\circ}$, since they occur in the western Pacific subduction zones. Another set of events originate from the Andean subduction zone, having backazimuths of $240^{\circ}$ to $310^{\circ}$ (Fig. 4).

Handling of data from several data centres can easily been achieved by using the SplitLab environment (Wüstefeld et al., 2008). In total, we were able to identify 663 SKS shear wave splitting events. With SplitLab, we were able to quickly manage the entire splitting process, and it provides a comprehensive interface to simultaneously compare different splitting techniques (Fig. 5) and to test various filter time window combinations. This proved helpful since small delay times make careful data and filter selection necessary. Where possible, we used either raw data or a broad band pass filter $(0.011 \mathrm{~Hz})$. The narrowest filter we applied on an individual seismogram was a $0.020 .2 \mathrm{~Hz}$ band pass. The dominant frequency of an SKS phase is usually around $0.125 \mathrm{~Hz}$. Narrow filtering usually results in a Null event (i.e., no energy on the initial transverse component) and thus has a strong influence on the resulting splitting parameter estimates. Note, that care has to be taken to find a good trade off between signal fidelity and noise suppression. Levin et al. (1999) tested the influence of filtering on synthetic seismograms modelled for a multilayer case. They found that the apparent splitting parameters are most variable for the lowest band pass filter applied, in their case $0.050 .15 \mathrm{~Hz}$. We remark that low frequent narrow filters (e.g., $0.010 .15 \mathrm{~Hz}$ ) may in general be applied for shear wave splitting measurements. These require however a very good signal to noise ratio $(>10)$, defined as the ratio of the maximum amplitude on the radial component to the standard deviation of the transverse components, both after the removal of splitting (Restivo and Helffrich,

Table 1

Splitting results of the stations on the East European Craton.

\begin{tabular}{|c|c|c|c|c|c|c|c|c|c|}
\hline \multirow[t]{2}{*}{ Station } & \multirow[t]{2}{*}{ Lat } & \multirow[t]{2}{*}{ Long } & \multirow[t]{2}{*}{ Network } & \multirow[t]{2}{*}{ Total } & \multirow[t]{2}{*}{ Automatic / manual } & \multicolumn{2}{|l|}{$\Phi$} & \multicolumn{2}{|l|}{$\mathrm{d} t$} \\
\hline & & & & & & Upper & $\overline{\text { Lower }}$ & Upper & Lower \\
\hline AKTK & 50.435 & 58.02 & Kazachstan & 35 & $\begin{array}{l}6 g+1 f+10 p+2 f N+16 g N \\
3 g+6 f+6 p+11 f N+9 g N\end{array}$ & $56^{\circ}$ & & 0.5 & \\
\hline ARU & 56.43 & 58.56 & GSN & 139 & $\begin{array}{l}34 g+19 f+35 p+20 f N+31 g N \\
49 g+32 f+11 p+26 f N+21 g N\end{array}$ & $55^{\circ}$ & $78^{\circ}$ & 0.5 & 0.4 \\
\hline KEV & 69.76 & 27.01 & GSN & 44 & $\begin{array}{l}4 g+3 f+12 p+9 f N+16 g N \\
3 g+4 f+0 p+19 f N+18 g N\end{array}$ & $0^{\circ}$ & & 0.4 & \\
\hline $\mathrm{KIEV}^{\mathrm{a}}$ & 50.69 & 29.21 & GSN & 61 & $\begin{array}{l}3 g+4 f+24 p+3 f N+27 g N \\
19 g+14 f+5 p+13 f N+10 g N\end{array}$ & $75^{\circ}$ & & 1.1 & \\
\hline LVZ & 67.9 & 34.65 & GSN & 41 & $\begin{array}{l}10 g+8 f+6 p+7 f N+10 g N \\
16 g+7 f+1 p+9 f N+8 g N\end{array}$ & $10^{\circ}$ & & 1.1 & \\
\hline MHV & 54.96 & 37.77 & GEOFON & 61 & $\begin{array}{l}4 g+2 f+10 p+2 f N+13 g N \\
5 g+6 f+3 p+8 f N+9 g N\end{array}$ & $35^{\circ}$ & & 1.1 & \\
\hline NE51 & 59.881 & 29.826 & NARS & 12 & $\begin{array}{l}4 g+0 f+3 p+2 f N+3 g N \\
5 g+4 f+0 p+0 f N+3 g N\end{array}$ & $47^{\circ}$ & & 0.7 & \\
\hline $\mathrm{NE} 52^{\mathrm{a}}$ & 57.819 & 28.39 & NARS & 8 & $\begin{array}{l}1 g+0 f+4 p+0 f N+3 g N \\
1 g+0 f+0 p+5 f N+2 g N\end{array}$ & $60^{\circ \mathrm{a}}$ & & 0.8 & \\
\hline NE53 & 54.904 & 26.793 & NARS & 18 & $\begin{array}{l}0 g+1 f+5 p+3 f N+9 g N \\
2 g+1 f+3 p+6 f N+6 g N\end{array}$ & NS & & $<0.5$ & \\
\hline NE54 & 52.568 & 23.861 & NARS & 3 & $\begin{array}{l}1 g+0 f+1 p+0 f N+1 g N \\
1 g+1 f+0 p+1 f N+0 g N\end{array}$ & $60^{\circ}$ & & 0.6 & \\
\hline NE55 & 49.716 & 29.656 & NARS & 6 & $\begin{array}{l}0 g+1 f+2 p+0 f N+3 g N \\
1 g+0 f+0 p+1 f N+4 g N\end{array}$ & $37^{\circ}$ & & 0.8 & \\
\hline NE56 & 46.676 & 30.899 & NARS & 6 & $\begin{array}{l}4 g+0 f+1 p+0 f N+1 g N \\
3 g+1 f+0 p+0 f N+2 g N\end{array}$ & $45^{\circ}$ & & 0.6 & \\
\hline $\mathrm{OBN}^{\mathrm{b}}$ & 55.11 & 36.57 & GSN & 115 & $\begin{array}{l}12 g+16 f+42 p+8 f N+37 g N \\
26 g+22 f+13 p+24 f N+30 g N\end{array}$ & $30^{\circ}$ & $70^{\circ}$ & 0.8 & 0.5 \\
\hline PUL & 59.77 & 30.32 & GEOFON & 20 & $\begin{array}{l}2 g+1 f+5 p+0 f N+12 g N \\
4 g+4 f+0 p+1 f N+11 g N\end{array}$ & $41^{\circ}$ & & 0.7 & \\
\hline SUW & 54.012 & 23.18 & GEOFON & 72 & $\begin{array}{l}13 g+11 f+20 p+8 f N+20 g N \\
19 g+21 f+2 p+15 f N+15 g N\end{array}$ & $70^{\circ}$ & & 0.8 & \\
\hline TRTE & 58.38 & 26.72 & GEOFON & 22 & $\begin{array}{l}1 g+5 f+7 p+3 f N+6 g N \\
6 g+7 f+0 p+5 f N+4 g N\end{array}$ & $35^{\circ}$ & & 0.7 & \\
\hline
\end{tabular}

Manual and automatic quality and Null assignment are given: $g=$ good, $f=$ fair, $p=$ poor, $f N=$ fair Null, $g N=$ good Null.

a More complex geometry possible/beyond resolvability.

b For 2 s dominant frequency. 
1999). For a detailed discussion on shear wave splitting processing we refer to Vecsey et al. (2008).

The quality of our measurements has been determined using the automatic method defined by Wüstefeld and Bokelmann (2007). This method reliably detects Null measurements and assigns a quality indicator, as reported in Table 1 . An automatic detection is important to produce a homogeneous dataset for all stations by eliminating possible bias for specific stations. Such bias can be caused by a low signal to noise ratio, in which case the seismologist tends to assign a too high quality. Furthermore, subjective biases can be caused by a sequence of Null events followed by a rather poor event (or a sequence of good events followed by a fair one). A dataset with automatic Null and quality detection is therefore reproducible with fixed criteria for each assignment, and thus objective.

\section{Results}

We analysed the shear wave splitting of 16 broad band seismo graph stations on the East European Craton. Fig. 6 and Table 1 give an overview of the results (see also supplemental material). A detailed discussion) of each station can be found in Wüstefeld (2007, http:// www.gm.univ montp2.fr/splitting/). Station LVZ (Fig. 7) has also been discussed in Wüstefeld and Bokelmann (2007). The observed splitting on the EEC is generally low, with delay times varying between 0.4 and $1.1 \mathrm{~s}$.

Wherever backazimuthal variation could not simply be explained by a single layer of anisotropy, we have tested for a two layer case
(Silver and Savage, 1994). Only at OBN and ARU, a two layer model explained the observations better than a single layer of horizontal anisotropy with sufficient confidence. At OBN, located close to the central cratonic triple junction of rifts (Fig. 1), the observed overall anisotropy is relatively small. The mean of the good non Null measurements is $0.6 \mathrm{~s}$. Therefore, any complex anisotropic structure is hard to distinguish. Our two layer model for OBN represents the best fit with the obtained splitting parameters. More years of measurements might eventually lead to a closer insight into the anisotropic structure of these two stations in particular, and the EEC as a whole. At $70 \mathrm{~km}$ east of OBN, the station MHV only observations from events with easterly backazimuths are available. These show results parallel to events from the same backazimuthal range at OBN. However, the lack of backazimuthal coverage renders the interpreta tion of this more complex anisotropy difficult.

At ARU, in the central Uralian foredeep, Levin et al. (1999) identified a three layer case with the lower two layers dipping in opposite directions. A simpler two layer model explains our SKS splitting observations within similar error margins. Station AKTK, in the southern Ural Mountains (Fig. 1), has only a quarter of the number of events available for ARU (Table 1), with most results only available for events from easterly backazimuths. The proposed (one layer model) anisotropy orientation is parallel to the upper layer of ARU.

Anisotropy at station KIEV proved to be particularly difficult to detect. Despite 17 years of 3 component digital data available, only few events showed reasonably well the effect of shear wave splitting. We
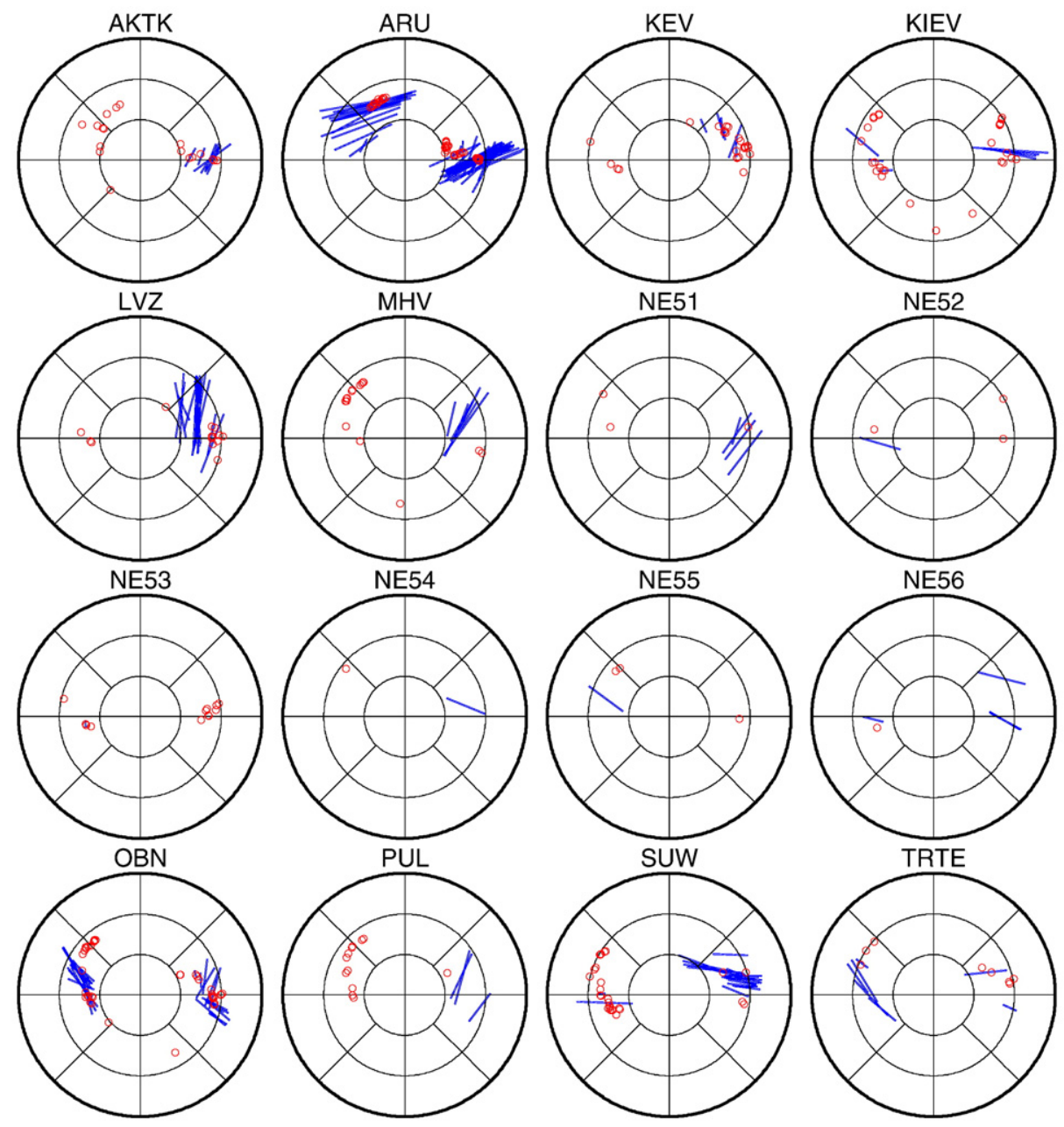

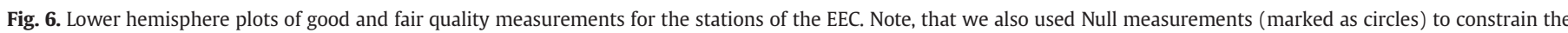
seismic fast orientation $\Phi$ (cf. Fig. 6). Gridlines are in $5^{\circ}$ steps from the centre. 


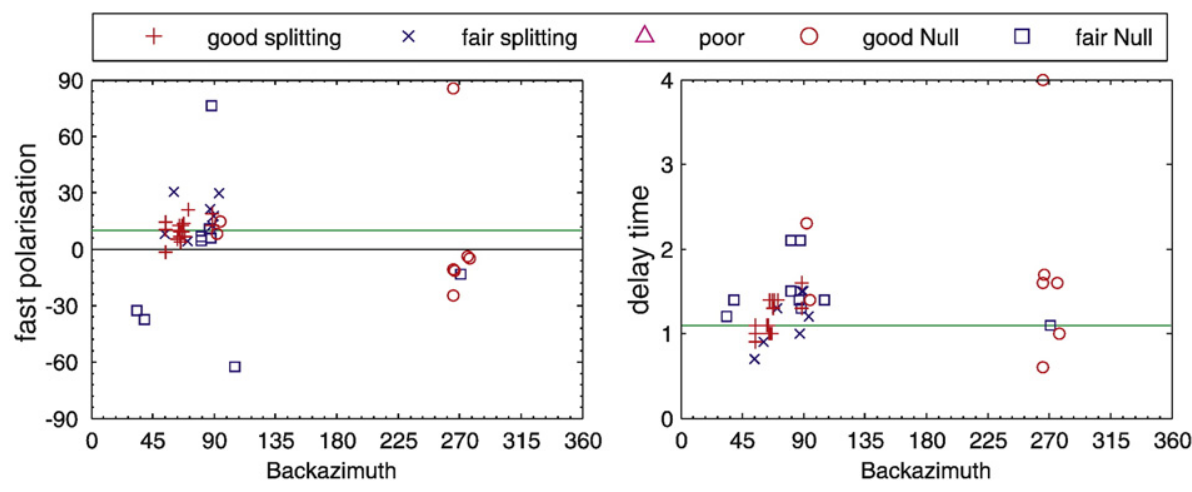

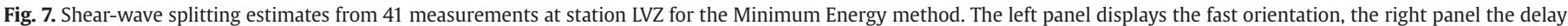

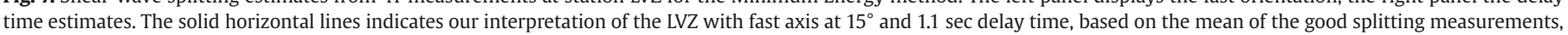
shown by + signs. Note that the placement of the Nulls agrees with that interpretation.

observed many Nulls, often from similar backazimuths as non Nulls. The automated Null detection (Wüstefeld and Bokelmann, 2007), based on characteristic differences between the cross correlation and minimum energy splitting methods, proved to be rather helpful for KIEV (Table 1). The manual selection of events showed splitting directions close to the actual backazimuth of the corresponding event. The automated Null detection method identified many of those events as Nulls. Apparently, subjective Null detection tends to prefer non Nulls. The seismologist interprets small energy on the transverse component as evidence for a non Null event, especially in cases when the separation of fast and slow component is below resolution of splitting methods.

\section{Discussion}

On the EEC, teleseismic shear waves from a broad range of backazimuths can be recorded, notably from the Andean and South West Pacific subduction zones. Interestingly, this good coverage lead only to a relatively small selection of splitting measurements per station. This must be attributed to a low signal to noise ratio, probably due to large sediment thickness, accompanied by a generally low level of anisotropy. Furthermore, complex anisotropy patterns, as may be suggested for some stations are at the limit of resolution of the method applied here.

\subsection{How can we interpret the results?}

Before we can address the major questions posed in the introduction, we need to know the nature of the seismic anisotropy that is observed on the EEC. Does it arise from ongoing deformation in the asthenosphere, or does it rather represent the fossil deformation of the lithosphere? Responding to this question would be easier, if we had stronger constraints on the depth range of the anisotropy. We can nevertheless address the nature of the anisotropy by correlating with expected anisotropy orientations that would result either from asthenospheric flow, or from frozen lithospheric deformation. In the first case, anisotropy can be expected to be more or less parallel to the absolute plate motion direction. In the second case, it would be parallel to crustal fabric, at least in regions where crust and upper mantle have been deformed coherently (Silver, 1996). In the following we thus test these two hypotheses.

\subsection{Correlation with plate motion}

The plate velocity of the EEC, relative to the most recently proposed hotspot reference frame HS3, is about $20 \mathrm{~mm} / \mathrm{yr}$ (Gripp and Gordon, 2002), and thus relatively small, and it was even smaller relative to the earlier hotspot reference frame HS2, about $10 \mathrm{~mm} / \mathrm{yr}$
(Gripp and Gordon, 1990). It is however significantly different from zero and might thus in principle be able to produce a CPO. NoNetRotation frames would suggest similar plate velocities, but pointing in the opposite direction (Drewes, 1998; Sella et al., 2002). This would produce a similar CPO.

Fig. 8 shows the angular difference at each station between the plate motion direction and the observed $\Phi$, within $0^{\circ}$ and $90^{\circ}$, which reflect parallel and perpendicular orientations, respectively. Indepen dent of the considered model, the correlation between plate motion direction and $\Phi$ is poor.

Good coherence between the observed fast axis and the plate motion vector is only observed at ARU, NE51/PUL and NE54. Since plate motion is uniform and splitting orientations change over short spatial distances, particularly in the west, this coherence seems to be only coincidental. At the other stations, plate motion vectors and $\Phi$ are almost perpendicular. The absence of coherence between splitting and plate motion indicates only a small, if any, asthenospheric contribution to shear wave splitting. Topography at the base of the lithosphere might also cause small scale variations (Bormann et al., 1993).
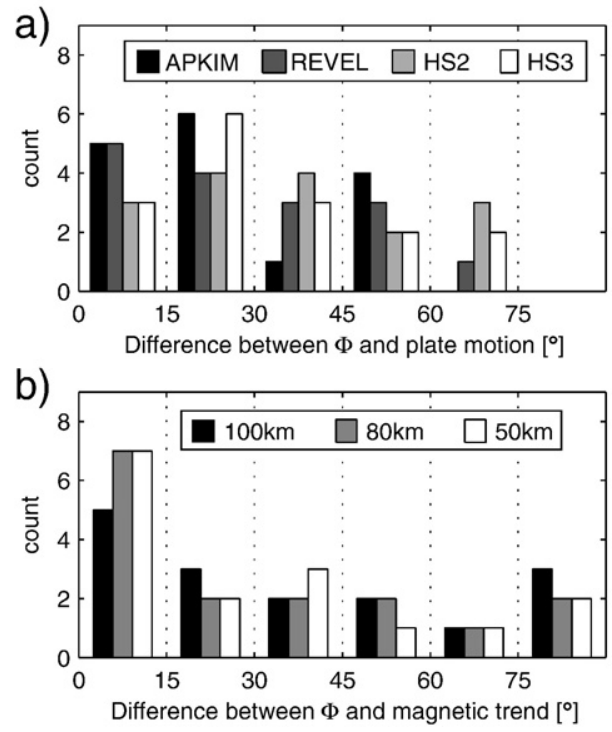

Fig. 8. a) Angular difference between the seismic fast orientation $\Phi$ and the absolute plate motion direction, as calculated from various models. The splitting directions of the 16 analyzed stations on the EEC show no correlation with any of the 4 plate motion models. b) Histogram of the angular difference between the seismic fast orientation $\Phi$ and magnetic preferred orientations for three search radii. 


\subsection{Correlation with crustal fabric via magnetic lineations}

Lithospheric anisotropy, on the other hand, corresponds to the frozen record of past tectonic processes. If the accompanying deformation is vertically coherent (Silver, 1996), one should expect a parallelism between the fast $\mathrm{S}$ wave orientation and geological fabric at the surface. Studying North America, Bokelmann and Wüstefeld (2009) show indeed an excellent agreement of the two quantities for most of the Canadian Shield, strongly suggesting vertically coherent deformation for that craton. For the EEC, thick sediments cover much of the surface extent (Zonenshain et al., 1990), impeding a geological determination of crustal fabric, except for the few areas of exposed precambrian crust. For an ancient region as the $\mathrm{EEC}$, topography is mostly eroded. This requires indirect observations to determine crustal structure and fabric.

Bogdanova et al. (1996) pointed out that the long wavelength magnetic anomalies of T MAGSAT data correspond to first order to the three major units of the EEC. Two large positive anomalies in the south coincide with Sarmatia and Volgo Uralia, respectively. In contrast, Fennoscandia is characterized by more magnetic inhomogeneity, possibly related to the complex mosaic of crustal provinces. High gradient zones coincide remarkably well with the ancient suture zones combining the three segments of the EEC.

The fact that splitting orientations are rather consistent within each tectonic unit while being different from one tectonic unit to another (Fig. 3) already represents a basic argument for a lithospheric origin of the anisotropy. We also note that a higher resolution experiment in Finland (Vecsey et al., 2007) has shown a variation across that portion of the Fennoscandia block, that agrees well with the nearly North South fast directions in the North (at stations KEV and LVZ) and more NE SW fast directions to the South (at stations PUL and NE51).

The subsurface imprints of tectonic activities in the crust are clearly visible in magnetic maps (e.g. Fig. 3) and can thus be used to constrain crustal fabric. Alternatively, gravity anomalies might be used (Simons and van der Hilst, 2003), but they offer lower resolution than magnetic data. The longer wavelength portion of the gravity field may also still contain information from the mantle, which is not desirable for this study, since we wish to compare mantle fabric (via seismic anisotropy) with crustal fabric.

An important issue is how magnetic structures are related with the tectonic regime, and more specifically, with seismic anisotropy. In transpressional regimes, folding and faulting yield magnetic (and other types of) structures parallel to the collision front. As has been shown, fast seismic $S$ wave orientations in orogens are also oriented along the main trend of the mountain chain. We can thus expect a parallelism between magnetic lineaments and seismic fast axes.

Visual inspection of map data for (linear) features does not necessarily reveal all structures, since potential variations at smaller scales are not visible or hidden by the colormap. We prefer using an objective and reproducible method for extracting lineaments from the magnetic maps. Applying a Radon Transform to test regions around the seismic stations provides such objective measure (see Appendix A). Bokelmann and Wüstefeld (2009) used that technique to identify very good correlation between magnetic and shear wave splitting data in parts of North America. The technique uses a Radon transformation, performed on circular portions of the residual magnetic map of Korhonen et al. (2007, see Fig. 3) around the stations. The test radii are 50,80 and $100 \mathrm{~km}$, respectively (cf. Fig. A1c and d). The smallest circle thus represents approximately the Fresnel zone in the uppermost mantle for shear waves with $10 \mathrm{~s}$ dominant period. This ensures that similar regions of crust and mantle are examined. Similar azimuths recovered from several test regions indicate the robustness of the result. Fig. A1d shows the result of a Radon Transform around station TRTE for an $80 \mathrm{~km}$ radius. The linear features of the magnetic anomalies are well resolved and align well with the observed fast $\mathrm{S}$ wave direction.
Magnetic anomalies reflect compositional and/or structural con trasts in the crust. A parallelism between splitting orientations (associated with mantle processes) and crustal magnetic lineaments thus suggests vertically coherent deformation (VCD). The results of that comparison for stations of the EEC are given in Table 2.

Fig. 9 shows the misfit between the fast splitting orientation and the magnetic lineament for all the 16 stations at different radii, grouped for each tectonic unit. In the PLTB and Fenno Scandia the fit is generally fairly good. This is striking, since fast direction vary strongly between the different stations. In fact, there is a much better correlation between seismic and magnetic directions than between the seismic directions at the various stations. The good correlation for all those stations suggests vertically coherent deformation of crust and lithosphere for Fenno Scandia and the PLTB. Interestingly, stations at the western edge of the EEC show only weak correlation (KEV, SUW). Perhaps the location of these stations over the transition from thick lithosphere to thinner and more mobile lithosphere to the west (see Fig. 2) helps to explain this anomalous behaviour (Wylegalla et al., 1999; Wiejacz, 2001).

For Sarmatia, however, there is no correlation between seismic fast axes and magnetic lineations. The correlation is nearly antiparallel for the station MHV, and oblique at KIEV and OBN. MHV and OBN are located close to the mutually perpendicular Central Russian Rift and the Pachelma Rift (Fig. 2), both of which showing clear magnetic signatures. In fact, the presence of a rift can strongly perturb the magnetic signal, since they are associated with mafic material (Bogdanova et al., 2006). This can also be seen for stations on the McKenzie dyke swarm in Northern Canada: at those stations there were two sets of magnetic lineations present, one associated with crustal fabric, and one with the dykes in the area (Bokelmann and Wüstefeld, 2009). The anisotropy was also difficult to determine for those stations, including KIEV. The observed splitting orientations are less well constrained, showing a complex backazimuthal pattern and many Nulls, which is especially true for KIEV. It is therefore plausible to assume that low anisotropy in Central and North Eastern Sarmatia exist and poorly constrained fast directions thus causing the poor correlation with magnetic trends.

We note also that seismic anisotropy is not yet well understood in a rift setting. While the extension of the VCD model would suggest rift normal fast directions (Silver, 1996), both rift normal and rift parallel orientations have been found in rift zones (e.g. Gao et al., 1997; Walker et al., 2004; Kendall et al., 2006). The effect on the anisotropy in a stable shield caused by two superimposing rifting episodes is expected to be complex and can probably not be determined from a single station.

The still acceptable misfits of $30^{\circ}$ and $15^{\circ}$ for the Ural stations AKTK and ARU, respectively, might be explained by (a) the distance from the deformation front and (b) the strong magnetic anomaly north of ARU, which trends ENE WSW.

\subsection{Nature of the anisotropy under the Eastern European Craton}

The weak correlation of the shear wave splitting fast orientations $\Phi$ with absolute plate motion vectors of various reference systems does not favour a model of asthenospheric mantle flow beneath the East European Craton. Such a model might, however, be valid for the adjacent areas (Bormann et al., 1993), though rejected by a growing number of studies (e.g., Babuška et al., 1993; Plomerová et al., 1998; Brechner et al., 1998; Babuška and Plomerová, 2006). Directly beneath the EEC however, our data clearly favour anisotropy frozen into the lithosphere. The relative weakness of anisotropy, (delay times between 0.4 and $1.1 \mathrm{~s}$ ), does not allow to constrain a two layer model, which might account for asthenospheric contributions, if present. For the EEC, the coherence of anisotropy within tectonic units, and variation between units suggested that the anisotropy is primarily of lithospheric ('fossil') origin, and this was confirmed by the correlation with magnetic lineaments for Fenno Scandia and the PLTB. 
An asthenospheric contribution is apparently present for large parts of the Earth. Gung et al. (2003) interpret the presence of $V_{\mathrm{SH}}>V_{\mathrm{SV}}$ anisotropy beneath continents at depths between $200 \mathrm{~km}$ and $400 \mathrm{~km}$ as an indicator of present day simple shear. This would be consistent with some shear wave splitting studies, which propose a two layer aniso tropy, one frozen in into the upper layer, and a deeper layer, related to ongoing processes (e.g. Levin et al., 1999; Fouch et al., 2000; Heintz and Kennett, 2006). For Fennoscandia, Pedersen et al. (2006) used Rayleigh and Love phase velocities to conclude that the lithosphere beneath the Baltic Shield contains little azimuthal anisotropy, but that coherent azimuthal anisotropy does exist below the lithosphere. In contrast, a joint inversion of body wave anisotropy in the same area by Vecsey et al. (2007) interprets the existence of several anisotropic domains as fossil olivine fabric frozen in the lithosphere before assemblage. Our findings support this latter interpretation, which is also in line with Fouch and Rondenay (2006). They suggest that the oceanic asthenospheric flow model might not be appropriate beneath continents. Furthermore, Becker et al. (2007) proposed a stochastic model of anisotropy, which shows a correlation length of splitting parameters of $L \sim 1600 \mathrm{~km}$ for stable continental regions, that the authors relate to large scale tectonic processes (lithospheric anisotropy). In oceanic regions the correlation length determined from surface waves is much longer $(L \sim 4500 \mathrm{~km})$, probably reflecting asthenospheric anisotropy under oceans.

The question of the presence of an asthenosphere is especially interesting for cratons, e.g., to know whether they are firmly coupled with mantle convection or not. For the Canadian shield, a second layer which has the characteristics of 'asthenospheric flow' anisotropy was indeed required to explain the 'relative variation paradox' between $\mathrm{P}$ and S wave delays (Bokelmann and Silver, 2000). This was later used to study plate mantle interaction under the craton in more detail (Bokelmann, 2002a,b). Surface wave studies also suggest presence of asthenospheric anisotropy under certain cratons (e.g., Debayle et al., 2005).

The availability of information about the geology of the EEC in international literature is only growing by now and the station coverage of the vast area of the East European Craton is extremely sparse at this moment. The findings of this study should however provide a framework for planning further studies, focused on specific parts of the EEC. Suitable regions for such seismic experiment would be for instance an array over the Polish Belarus Lithuanian Terrane, the Pachelma Rift/Central Russian Rift system junction close to OBN and MHV and across the Ural Mountains. The EEC represents one of the thickest blocks of lithosphere on Earth, and it is probably a place of strong plate mantle interaction. Better understanding of the aniso tropy under Eastern Europe is therefore essential for understanding convection processes in the deep Earth (e.g., Bokelmann, 2002a), and

Table 2

Difference (in degrees) between upper-layer seismic fast-axis orientation $\Phi$ and dominant magnetic trend $\Psi$ for each stations of the EEC for different radii.

\begin{tabular}{|c|c|c|c|c|c|c|c|}
\hline \multirow[t]{2}{*}{ Station } & \multirow{2}{*}{$\frac{\text { Fast orientation }}{\Phi}$} & \multicolumn{3}{|c|}{ Magnetic Orientation $\Psi$} & \multicolumn{3}{|l|}{ Misfit } \\
\hline & & $50 \mathrm{~km}$ & $80 \mathrm{~km}$ & $100 \mathrm{~km}$ & $50 \mathrm{~km}$ & $80 \mathrm{~km}$ & $100 \mathrm{~km}$ \\
\hline AKTK & 56 & 24 & 22 & 24 & 32 & 34 & 32 \\
\hline ARU & 55 & 69 & 71 & 71 & 14 & 16 & 16 \\
\hline KEV & 0 & 47 & 68 & 77 & 47 & 68 & 77 \\
\hline KIEV & 75 & 35 & 28 & 29 & 40 & 47 & 46 \\
\hline LVZ & 10 & 59 & 30 & 25 & 69 & 20 & 15 \\
\hline MHV & 35 & 51 & 53 & 74 & 86 & 88 & 71 \\
\hline NE51 & 47 & 67 & 57 & 49 & 20 & 10 & 2 \\
\hline NE52 & 60 & 66 & 59 & 58 & 6 & 1 & 2 \\
\hline NE53 & 0 & 4 & 1 & 9 & 4 & 1 & 9 \\
\hline NE54 & 60 & 10 & 48 & 46 & 50 & 12 & 14 \\
\hline NE55 & 37 & 40 & 30 & 18 & 3 & 7 & 19 \\
\hline NE56 & 45 & 21 & 11 & 11 & 24 & 34 & 34 \\
\hline OBN & 30 & 66 & 89 & 70 & 84 & 59 & 40 \\
\hline PUL & 41 & 60 & 49 & 48 & 19 & 8 & 7 \\
\hline SUW & 70 & 29 & 22 & 26 & 81 & 88 & 84 \\
\hline TRTE & 35 & 44 & 44 & 46 & 9 & 9 & 11 \\
\hline
\end{tabular}

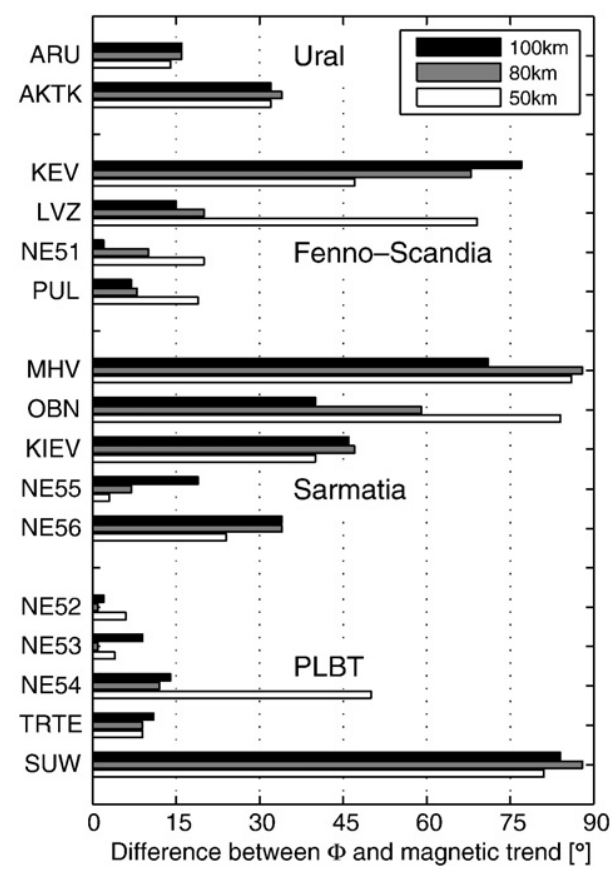

Fig. 9. Misfit between magnetic lineaments and seismic fast orientation for different test radii $(50,80$, and $100 \mathrm{~km})$ around each station, grouped by tectonic unit. In the PLTB and Fenno-Scandia there is generally good agreement, except for stations on the western edge of the craton (KEV, SUW). There is no correlation for Sarmatia, the reasons for which are discussed in the text.

well as their effect on the motion of plates at the Earth's surface, and their tectonic evolution.

\section{Conclusions}

We analyzed the shear wave splitting of 16 broad band seismo graph stations on the East European Craton. The observed splitting is generally low, with delay times varying between 0.4 and $1.1 \mathrm{~s}$. This is in agreement with general findings in several other shield regions (Fouch and Rondenay, 2006), although some of the highest splitting delay times $(>2 s)$ on the globe are observed on the Canadian Shield.

In order to constrain the origin of anisotropy we compared the observed fast split azimuths $\Phi$ with several datasets: the $\Phi$ are quite homogeneously oriented inside each tectonic unit but display rather strong variations between the tectonic units, suggesting "frozen in", lithospheric anisotropy inside each block. Such interpretation is supported by a lack of correlation of $\Phi$ with plate motion direction. Finally, the trend of (crustal) magnetic structures aligns relatively well with the observed splitting orientations. Of 16 analysed stations, 7 agree within $15^{\circ}, 9$ within $30^{\circ}$. This is remarkable given the sparse station distribution and varying tectonic setting. We interpret this result as vertically coherent deformation throughout the crust and the upper most mantle, supporting the idea that shear wave splitting under cratons may be dominated by the signature of the last tectonic event. It appears clear that magnetic data are useful as a proxy for crustal fabric orientation, which is especially valuable in inaccessible regions or regions with thick sediments covering the underlying basement.

There appears to be no strong indicator of present day mantle flow causing the anisotropy beneath the EEC. The spatial coherence of $\Phi$ across the TESZ is however an intriguing observation. If caused by present day mantle flow, this would require that the same mechanism applies across the TTZ. Such mechanism could involve lateral mechanical erosion at the edge of the EEC lithosphere that would be consistent with the thinner lithosphere observed beneath Sarmatia. Such interpretation is beyond the limit of resolution of surface wave tomography and seismic anisotropy studies available at this moment. 
For the remaining stations of the EEC, no indicator of mantle flow deviated by the keel of the EEC can be observed in splitting measure ments and the observed delay times are too small to resolve any dipping anisotropies.

\section{Acknowledgements}

We would like to thank the IRIS, NARS, and Geofon networks for providing data, E. Debayle for the tomography model and A. Vauchez for fruitful discussions. This work was performed using funding of the European Community (contract MIRG CT 2004 003953). The sugges tions of two anonymous reviewers helped to improve the manuscript. The splitting results of the 16 stations on the EEC analysed in this study can be found in the supplemental material. A detailed discussion of each station is provided in Wüstefeld (2007), available at http:// www.gm.univ montp2.fr/splitting.

\section{Appendix A}

An objective method to identify linear features of a complex map can be based on the Radon Transform, as has been done in other recent approaches (Zhang et al., 2006; Hansen and deRidder, 2006; Bokelmann and Wüstefeld, 2009):

$R[f](\theta, s)=\int_{\infty}^{\infty} \int_{\infty}^{\infty} f(x, y) \delta(x \cos \theta+y \sin \theta-s) \mathrm{d} x \mathrm{~d} y$

The transform corresponds to a slant stack along a line in direction $\theta$ of the magnetic field $f(x, y)$. Linear features in $f(x, y)$ are projected into a point in $R[f]$ at angle $\theta$ and offset $s$, whereas points in $f(x, y)$ are represented as sinusoids in $R[f]$. Fig. A1a presents a synthetic dataset with two linear features with $30^{\circ}$ and $60^{\circ}$ azimuth, with positive and negative amplitude, respectively. Also shown are two point features of positive and negative amplitude. Fig. A1b shows the Radon Transform of this test. Note that the azimuths are well recovered at $30^{\circ}$ and $60^{\circ}$ as well as $210^{\circ}$ and $240^{\circ}$. The two point anomalies in a) are shown as sinoids in b), whose maximum amplitude represents their distances from the centre of the map.

The Radon Transform therefore gives a basis for either detecting individual lineaments in a map, or for characterizing preferred orientations by summing over all offsets $s$ in an appropriate way. Here, we are primarily interested in the overall preferred orientations rather individual lineaments, both of positive and negative amplitude. This "polarization" of the magnetic map can be identified by the measure

$P(\theta)=\int|R[f](\theta, s)|^{\lambda} \mathrm{d} s$

The exponent $\lambda$ may be chosen larger than 1 to enhance the effect. In this study, we have chosen $\lambda=2$.

We perform this transformation on residual magnetic data, based on aeromagnetic surveys and ship cruises relative to satellite magne tometer measurements and geomagnetic observatories (Fig. 3, Korhonen et al., 2007). This compilation has a resolution of $5 \mathrm{~km}$ and we downsampled the data to $1 \mathrm{~km}$. The orientations are calculated for several circular test regions around each station with radii of 50,80 and $100 \mathrm{~km}$, respectively (cf. Fig. A1c and d). Similar azimuths recovered from several test regions indicate the robustness of the result. Fig. A1d shows the results of a Radon Transform around station TRTE for an $80 \mathrm{~km}$ radius. The linear features of the magnetic anomalies are well
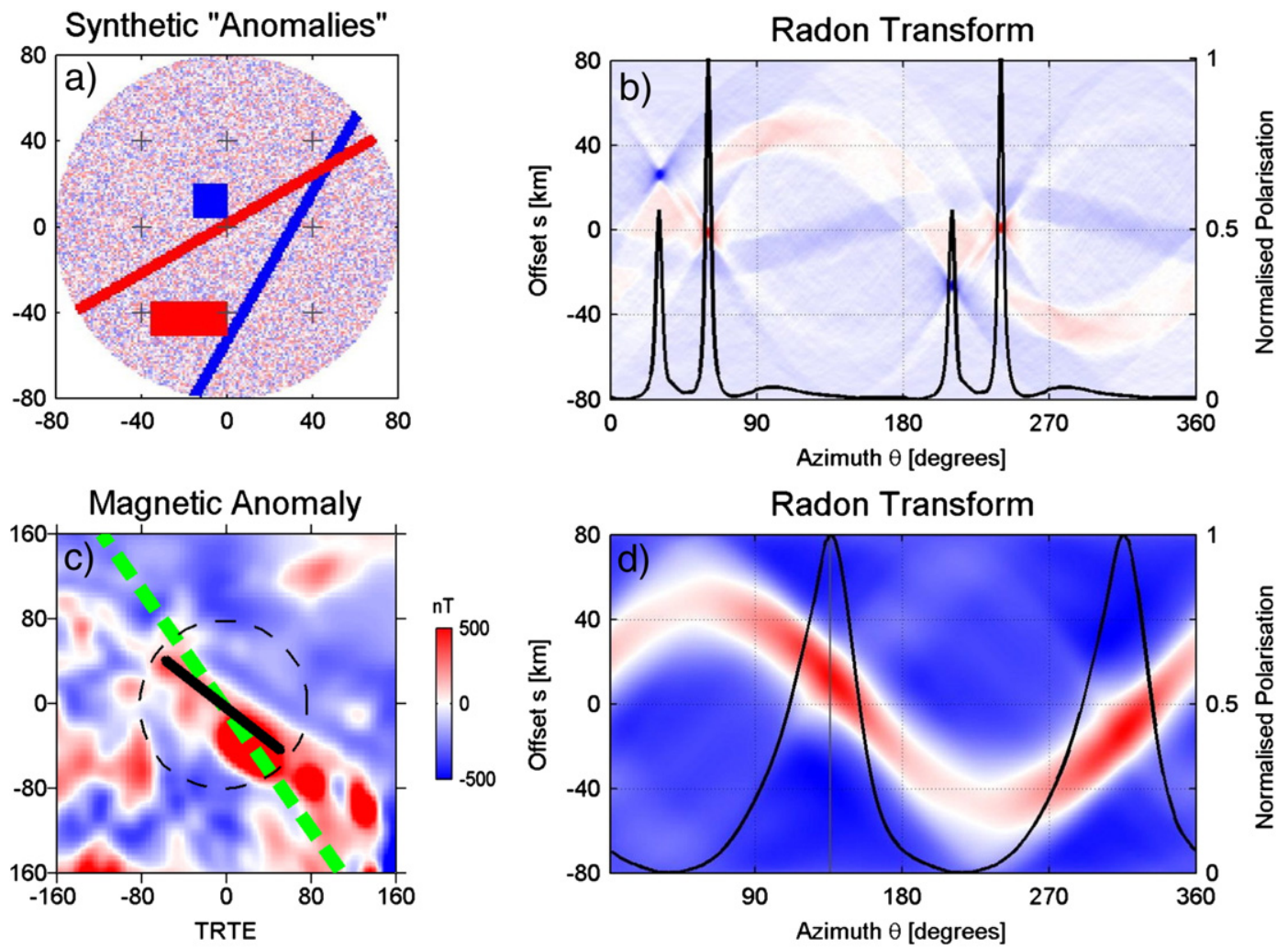

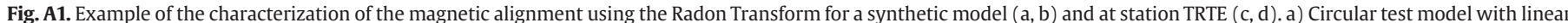

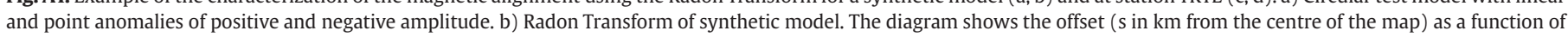

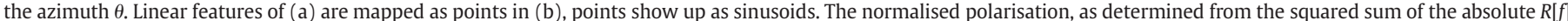

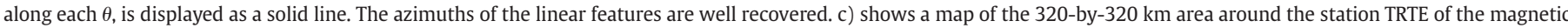

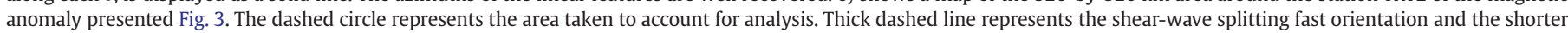
bar the dominant magnetic alignment. d) same as b) but for anomaly around TRTE. 
resolved and align well with the fast $\mathrm{S}$ wave direction observed at that station (see main text), thus confirming that the method is applicable to the real magnetic dataset.

\section{Appendix A. Supplementary data}

Supplementary data associated with this article can be found, in the online version, at doi:10.1016/j.tecto.2009.01.010.

\section{References}

Andrews, D.L., Gordon, R.G., Horner-Johnson, B.C., 2006. Uncertainties in plate reconstructions relative to the hotspots, Pacific-hotspot rotations and uncertainties for the past 68 million years. Geophys. J. Int. 166 (2), 939-951.

Argus, D.F., Gordon, R.G., 1991. No-net-rotation model of current plate velocities incorporating plate motion model NUVEL-1. Geophys. Res. Lett. 18, 2039-2042.

Artemieva, I.M., 2006 . Global $1^{\circ} \times 1^{\circ}$ thermal model TC1 for the continental lithosphere: implications for lithosphere secular evolution. Tectonophysics 416 (1-4), 245-277.

Artemieva, I.M., 2007. Dynamic topography of the East European craton: shedding light upon lithospheric structure, composition and mantle dynamics. Glob. Planet. Change 58, 411-434.

Assumpção, M., Heintz, M., Vauchez, A., Silva, M.E., 2006. Upper mantle anisotropy in SE and Central Brazil from SKS splitting: evidence of asthenospheric flow around a cratonic keel. Earth Planet. Sci. Lett. 250, 224-240.

Babuška, V., Cara, M., 1991. Seismic Anisotropy in the Earth. Kluwer Academic Publishers, Dordrecht.Babuška, V., Plomerová, J., Šílený, J., 1993. Models of seismic anisotropy in the deep continental lithosphere. Phys. Earth Planet. Inter. 78 (3-4), 167-191.

Babuška, V., Plomerová, J., 2006. European mantle lithosphere assembled from rigid microplates with inherited seismic anisotropy. Phys. Earth Planet. Inter. 158 (2-4) 264-280.

Babuška, V., Plomerová, J., Šílený, J., 1993. Models of seismic anisotropy in the deep continental lithosphere. PEPI 78 (3-4), 167-191

Babuška, V., Montagner, J.-P., Plomerová, J., Girardin, N., 1998. Age-dependent large-scale fabric of the mantle lithosphere as derived from surface-wave velocity anisotropy. Pure Appl. Geophys. 151 (2-4), 257-280.

Barruol, G., Granet, M., 2002. A Tertiary asthenospheric flow beneath the southern French Massif Central indicated by upper mantle seismic anisotropy and related to the west Mediterranean extension. Earth Planet. Sci. Lett. 202, 31-47.

Barruol, G., Silver, P.G., Vauchez, A., 1997. Seismic anisotropy in the eastern US: deep structure of a complex continental plate. J. Geophys. Res. 102 (B4), 8329-8348.

Barruol, G., Souriau, A., Vauchez, A., Diaz, J., Gallart, J., Tubia, J., Cuevas, J., 1998. Lithospheric anisotropy beneath the Pyrenees from shear wave splitting. J. Geophys. Res. 103 (B12), 30039-30053.

Bear, L.K., Pavlis, G.L., Bokelmann, G.H.R., 1999. Multi-wavelet analysis of three-component seismic arrays: application to measure effective anisotropy at Pinon Flats, California, Bulletin. Bull. Seismol. Soc. Am. 89 (3), 693-705

Becker, T.W., Browaeys, J.T., Jordan, T.H., 2007. Stochastic analysis of shear-wave splitting length scales. Earth Planet. Sci. Lett. 259, 526-540.

Behn, M.D., Conrad, C.P., Silver, P., 2004. Detection of upper mantle flow associated with the African Superplume. Earth Planet. Sci. Lett. 224, 259-274.

Ben Ismaïl, W., Mainprice, D., 1998. An olivine fabric database: an overview of upper mantle fabrics and seismic anisotropy. Tectonophysics 296 (1-2), 145-157.

Berthelsen, A., 1992. Mobile Europe. In: Blundell, D.J., Freeman, R., Mueller, S. (Eds.), A Continent Revealed-The European Geotraverse. Cambridge Univ. Press, Cambridge, pp. 11-32.

Bogdanova, S., 1996. Europrobe 1996 - Lithosphere dynamics. The EUROPROBE Secretariat Uppsala, chapter Eurobrigde, pp. 80-89.

Bogdanova, S.V., 2005. The East-European craton: some aspects of the Proterozoic evolution in its south-west. Mineral. Soc. Pol. Spec. Pap. 26, 18-24.

Bogdanova, S.V., Pashkevich, I.K., Gorbatschev, R., Orlyuk, M.I., 1996. Riphean rifting and major Palaeoproterozoic crustal boundaries in the basement of the East European Craton: geology and geophysics. Tectonophysics 268 (1-4), 1-21.

Bogdanova, S., Gorbatschev, R., Grad, M., Janik, T., Guterch, A., Kozlovskaya, E., Motuza, G., Skridlaite, G., Starostenko, V., Taran, L., 2006. EUROBRIDGE: new insight into the geodynamic evolution of the East European Craton. In: Gee, D.G., Stephenson, R.A. (Eds.), European Lithosphere Dynamics, Geol. Soc. London Memoirs, pp. 599-626.

Bokelmann, G.H.R., 1995. P-wave array polarization analysis and effective anisotropy of the brittle crust. Geophys. J. Int. 120 (1), 145-162.

Bokelmann, G.H.R., 2002a. Which forces drive North America? Geology 30 (11) 1027-1030.

Bokelmann, G.H.R., 2002b. Convection-driven motion of the North American craton: evidence from P-wave anisotropy. Geophys. J. Int. 248 (2), 278-287.

Bokelmann, G.H.R., Silver, P.G., 2000. Mantle variation within the Canadian Shield: travel times from the APT89 portable broadband transect. J. Geophys. Res. 105 579-605.

Bokelmann, G.H.R., Silver, P.G., 2002. Shear stress at the base of shield lithosphere. Geophys. Res. Lett. 29 (23), 2091. doi:10.1029/2002GL015925.

Bokelmann, G.H.R., Wüstefeld, A., 2009. Comparing crustal and mantle fabric from the North American craton using magnetics and seismic anisotropy. Earth Planet. Sci. Lett. 277 (3-4), 355-364.

Bormann, P., Burghardt, P., Makeyeva, L.I., Vinnik, L.P., 1993. Teleseismic shear-wave splitting and deformations in Central Europe. Phys. Earth Planet. Inter. 78, 157-166.
Bowman, J.R., Ando, M., 1987. Shear-wave splitting in the upper-mantle wedge above the Tonga subduction zone. Geophys. J. R. Astron. Soc. 88, 25-41.

Brechner, S., Klinge, K., Krüger, F., Plenefisch, T., 1998. Backazimuthal variations of splitting parameters of teleseismic SKS phases observed at the broadband stations in Germany. Pure Appl. Geophys. 151 (2-4), 305-331.

Brown, D., Puchov, V., Alvarez-Marron, J., Perez-Estaun, A., 1996. The structural architecture of the footwall to the main Uralian Fault. Earth Sci. Rev. 40, 125-140.

Bruneton, M., Pedersen, H.A., Farra, V., Arndt, N.T., Vacher, P., Achauer, U., Alinaghi, A., Ansorge, J., Bock, G., Friederich, W., Grad, M., Guterch, A., Heikkinen, P., Hjelt, S., Hyvönen, T.L., Ikonen, J., Kissling, E., Komminaho, K., Korja, A., Kozlovskaya, E., Nevsky, M.V., Paulssen, H., Pavlenkova, N.I., Plomerová, J., Raita, T., Riznichenko, O.Y., Roberts, R.G., Sandoval, S., Sanina, I.A., Sharov, N.V., Shomali, Z.H., Tiikkainen, J., Wielandt, E., Wilegalla, K., Yliniemi, J., Yurov, Y.G., 2004. Complex lithospheric structure under the central Baltic Shield from surface wave tomography. J. Geophys. Res. 109 (B18), B10303. doi:10.1029/2003JB002947.

Chevrot, S., 2000. Multichannel analysis of shear wave splitting. J. Geophys. Res. 105 (B9), 21579-21590.

Debayle, E., Kennett, B., Priestley, K., 2005. Global azimuthal seismic anisotropy and the unique plate motion deformation of Australia. Nature 433, 509-512.

DeMets, C., Gordon, R.G., Argus, D.F., Stein, S., 1994. Effect of recent revisions to the geomagnetic reversal time scale on estimates of current plate motions. Geophys. Res. Lett. 21, 2191-2194.

Drewes, H., 1998. Combination of VLBI, SLR and GPS determined station velocities for actual plate kinematic and crustal deformation models. In: Forsberg, R., Feissel, M., Dietrich, R. (Eds.), IAG Symposia. Geodesy on the Move, vol. 119. Springer, pp. 377-382.

Dricker, I., Vinnik, L., Roecker, S., Makeyeva, L., 1999. Upper mantle flow in eastern Europe. Geophys. Res. Lett. 26 (9), 1219-1222.

Evans, M.S., Kendall, J., Willemann, R.J., 2006. Automated SKS splitting and upper-mantle anisotropy beneath Canadian seismic stations. Geophys. J. Int. 165 (3), 931-942.

Flesch, L.M., Holt, W.E., Silver, P.G., Stephenson, M., Wang, C., Chan, W.W., 2005. Constraining the extent of crust-mantle coupling in central Asia using GPS, geologic, and shear wave splitting data. Earth Planet. Sci. Lett. 238, 248-268.

Fontaine, F.R., Hooft, E.E.E., Burkett, P.G., Toomey, D.R., Solomon, S.C., Silver, P.G., 2005. Shear-wave splitting beneath the Galápagos archipelago. Geophys. Res. Lett. 32, 21308.

Fontaine, F.R., Barruol, G., Tommasi, A., Bokelmann, G.H.R., 2007. Upper-mantle flow beneath French Polynesia from shear wave splitting. Geophys. J. Int. 170 (3), 1262-1288.

Fouch, M.J., Rondenay, S., 2006. Seismic anisotropy beneath stable continental interiors. Phys. Earth Planet. Int. 158 (2-4), 292-320.

Fouch, M.J., Fischer, K.M., Parmentier, E.M., Wysession, M.E., Clarke, T.J., 2000. Shear wave splitting, continental keels, and patterns of mantle flow. J. Geophys. Res. 105 (B3), 6255-6275

Fukao, Y., 1984. Evidence from core-reflected shear waves for anisotropy in the earths mantle. Nature 309 (5970), 695-698.

Gao, S., Davis, P.M., Liu, H., Slack, P.D., Rigor, A.W., Zorin, Y.A., Mordvinova, V.V., Kozhevnikov, V.M., Logatchev, N.A., 1997. SKS splitting beneath continental rift zones. J. Geophys. Res. 102 (B10), 2281-22798.

Gao, S.S., Silver, P.G., Liu, K.H., 2002. Mantle discontinuities beneath Southern Africa. Geophys. Res. Lett. 29 (10), 1491 (doi:10.1029/2001GL013834).

Gorbatschev, R., Bogdanova, S., 1993. Frontiers in the Baltic shield. Precambrian Res. 64 (1-4), 3-21.

Grad, M., Jensen, S.L., Keller, G.R., Guterch, A., Thybo, H., Janik, T., Tiira, T., Yliniemi, J., Luosto, U., Motuza, G., Nasedkin, V., Czuba, W., Gaczyński, E., Środa, P., Miller, K.C., Wilde-Piórko, M., Komminaho, K., Jacyna, J., Korabliova, L., 2003. Crustal structure of the Trans-European suture zone region along POLONAISE97 seismic profile P4. J. Geophys. Res. 108, 2541

Gripp, A.E., Gordon, R.G., 1990. Current plate velocities relative to the hotspots incorporating the NUVEL-1 global plate motion model. Geophys. Res. Lett. 17 (8), 1109-1112.

Gripp, A.E., Gordon, R.G., 2002. Young tracks of hotspots and current plate velocities. Geophys. J. Int. 150, 321-361.

Gung, Y., Panning, M., Romanowicz, B., 2003. Global anisotropy and the thickness of continents. Nature 422, 707-711.

Hansen, R.O., deRidder, E., 2006. Linear feature analysis for aeromagnetic data. Geophysics 71 (6), L61-L67.

Heintz, M., Kennett, B.L.N., 2005. Continental scale shear wave splitting analysis: investigation of seismic anisotropy underneath the Australian continent. Earth Planet. Sci. Lett. 236, 106-119.

Heintz, M., Kennett, B.L.N., 2006. The apparently isotropic Australian upper mantle. Geophys. Res. Lett. 33, L15319.

Heintz, M., Vauchez, A., Assumpcao, M., Barruol, G., Egydio-Silva, M., 2003. Shear wave splitting in SE Brazil: an effect of active or fossil upper mantle flow, or both? Earth Planet. Sci. Lett. 211, 79-95.

Helffrich, G., Silver, P., Given, H., 1994. Shear-wave splitting variation over short spatial scales on continents. Geophys. J. Int. 119 (2), 561-573.

James, D.E., Assumpcao, M., 1996. Tectonic implications of S-wave anisotropy beneath SE Brazil. Geophys. J. Int 126 (1), 1-10.

Kendall, J.M., 1994. Teleseismic arrivals at a mid-ocean ridge: effect of mantle melt and anisotropy. Geophys. Res. Lett. 21, 301-304.

Kendall, J.M., 2000. Seismic anisotropy in the boundary layers of the mantle. In: Karato, S., Stixrude, L., Liebermann, R.C., Masters, T.G., Forte, A.M. (Eds.), Earth's Deep Interior: Mineral Physics and Tomography from the Atomic to the Global Scale. Geophysical Monograph Series, vol. 117. American Geophysical Union, pp. 149-175.

Kendall, J., Stuart, G., Ebinger, C., Bastow, I., Keir, D., 2005. Magma-assisted rifting in Ethiopia. Nature 433, 146-148. 
Kendall, J., Pilidou, S., Keir, D., Bastow, I., Stuart, G., Ayele, A., 2006. Mantle upwellings, melt migration and magma assisted rifting in Africa: insights from seismic anisotropy. In: Yirgu, G., Ebinger, C.J., Maguire, P.K.H. (Eds.), Structure and Evolution of the Rift Systems within the Afar Volcanic Province, Northeast Africa, pp. 57-74.

Korhonen, J.V., Fairhead, J.D., Hamoudi, M., Hemant, K., Lesur, V., Mandea, M., Maus, S., Purucker, M., Ravat, D., Sazonova, T., Thébault, E., 2007, Magnetic Anomaly Map of the World, published by Commission for Geological Map of the World, supported by UNESCO, 1st Edition, GTK, Helsinki, 2007. ISBN 978-952-217-000-2.

Kreemer, C., Holt, W.E., Haines, A.J., 2003. An integrated global model of present-day plate motions and plate boundary deformation. Geophys. J. Int. 154, 8-34

Levin, V., Park, J., 1997. Crustal anisotropy in the Ural Mtns foredeep from teleseismic receiver functions. Geophys. Res. Lett. 24, 1283-1286.

Levin, V., Menke, W., Park, J., 1999. Shear wave splitting in the Appalachians and the Urals: a case for multilayered anisotropy. J. Geophys. Res. 104 (B8), 17,975-17,994.

Levin, V., Droznin, D., Park, J., Gordeev, E., 2004. Detailed mapping of seismic anisotropy with local shear waves in southeastern Kamchatka. Geophys. J. Int. 158 (3), 1009-1023.

Long, M.D., van der Hilst, R.D., 2005. Estimating shear-wave splitting parameters from broadband recordings in Japan: a comparison of three methods. Bull. Seismol. Soc. Am. 95 (4), 1346-1358.

Mainprice, D., Silver, P.G., 1993. Interpretation of SKS-waves using samples from the subcontinental lithosphere. Phys. Earth Planet. Inter. 78, 257-280.

Mainprice, D., Barruol, G., ben Ismaïl, W., 2000. The seismic anisotropy of the earths mantle: from single crystal to polycrystal. In: Karato, S.I. (Ed.), Earths Deep Interior: Mineral Physics and Tomography from the Atomic to the Global Scale. Geophysical Monograph, vol. 117. AGU, Washington, D.C., pp. 237-264.

Makeyeva, L., Vinnik, L., Roecker, S., 1992. Shear wave splitting and small-scale convection in the continental upper mantle. Nature 358, 144-147.

Margheriti, L., Lucente, F.P., Pondrelli, S., 2003. SKS splitting measurements in the Apenninic-Tyrrhenian domain (Italy) and their relation with lithospheric subduction and mantle convection. J. Geophys. Res. 108, 2218.

McKenzie, D., 1979. Finite deformation during fluid flow. Geophys. J. Int. 58 (3), 689-715.

Montagner, J., 1986. Dimensional structure of the Indian Ocean inferred from long period surface waves. Geophys. Res. Lett. 13, 315-318.

Montagner, J., 1998. Where can seismic anisotropy be detected in the earths mantle? In boundary layers. Pure Appl. Geophys. 151 (2 - 4), 223-256.

Morgan, W., 1971. Convection plumes in the lower mantle. Nature 132, 42-43.

Muyzert, E., Paulsen, H., Snieder, R., 1999. A seismic cross-section through the east European continent. Geophys. J. Int. 136, 695-704.

Nakajima, J., Hasegawa, A., 2004. Shear-wave polarization anisotropy and subductioninduced flow in the mantle wedge of northeastern Japan. Earth Planet. Sci. Lett. 225, 365-377.

Nicolas, A., Christensen, N.I., 1987. Formation of anisotropy in upper mantle peridotites A review. In: Fuchs, K., Froideveaux, C. (Eds.), Composition Structure and Dynamics of the Lithosphere Asthenosphere System. AGU, Washington D.C., pp. 111-123.

Nicolas, A., Boudier, F., Boullier, A.M., 1973. Mechanisms of flow in naturally and experimentally deformed Peridotites. Am. J. Sci. 273, 853-876.

Pedersen, H., Bruneton, M., Maupin, V., 2006. Lithospheric and sublithospheric anisotropy beneath the Baltic shield from surface-wave analysis. Earth Planet. Sci. Lett. 244, 590-605.

Perez-Estaun, A., Brown, D., 1996. Uralides - a key to understanding collisional orogeny. In: Gee, D.G., Zeyen, H.J. (Eds.), EUROPROBE 1996 - Lithosphere Dynamics: Origin and Evolution of Continents. The EUROPROBE Secretariat, Uppsala University, pp. 80-89.

Pharaoh, T., England, R.W., Verniers, J., Zelazniewicz, A., 1997. Geological and geophysical studies in the Trans-European Suture zone. Geol. Mag. 134 (5), 585-590.

Plenefisch, T., Klinge, K., Kind, R., 2001. Upper mantle anisotropy at the transition zone of the Saxothuringicum and Moldanubicum in southeast Germany revealed by shear wave splitting. Geophys. J. Int. 144 (2), 309-319.

Plomerová, J., Babuška, V., Šílený, J., Horálek, J., 1998. Seismic anisotropy and velocity variations in the mantle beneath the Saxothuringicum-Moldanubicum contact in Central Europe. Pure Appl. Geophys. 151 (2-4), 365-394.

Plomerová, J., Margheriti, L., Park, J., Babuška, V., Pondrelli, S., Vecsey, L., Piccinini, D., Levin, V., Baccheschi, P., Salimbeni, S., 2006. Seismic anisotropy beneath the Northern Apennines (Italy): mantle flow or lithosphere fabric? Earth Planet. Sci. Lett. 247 (1-2), 157-170.

Restivo, A., Helffrich, G., 1999. Teleseismic shear wave splitting measurements in noisy environments. Geophys. J. Int. 137 (3), 821-830.

Rümpker, G., Silver, P.G., 1998. Apparent shear-wave splitting parameters in the presence of vertically varying anisotropy. Geophys. J. Int. 135 (3), 790-800.

Saltzer, R.L., Gaherty, J.B., Jordan, T.H., 2000. How are vertical shear wave splitting measurements affected by variations in the orientation of azimuthal anisotropy with depth? Geophys. J. Int., 141, 374-390.

Savage, M.K., 1999. Seismic anisotropy and mantle deformation: what have we learned from shear wave splitting. Rev. Geophys. 37, 69-106.

Schulte-Pelkum, V., Masters, G., Shearer, P.M., 2001. Upper mantle anisotropy from long-period P polarization. J. Geophys. Res. 106, 21917-21934.

Sella, G.F., Dixon, T.H., Mao, A., 2002. REVEL: a model for recent plate velocities from space geodesy. J. Geophys. Res. 107, B4.

Shcherback, N.P., 1991. The Precambrian Subdivision of the Ukrainian Shield and their Comparison with USSR and International Scales Geologicheskiy Zhurnal, vol. 4, pp. 3-9 (in Russian).

Sieminski, A., Liu, Q., Trampert, J., Tromp, J., 2007. Finite-frequency sensitivity of body waves to anisotropy based upon adjoint methods. Geophys. J. Int. 171, 368-389.
Sileny, J., Plomerova, J., 1996. Inversion of shear-wave splitting parameters to retrieve 3-D orientation of anisotropy in continental lithosphere. Phys. Earth Planet. Int. 95, 277-292.

Silver, P.G., 1996. Seismic anisotropy beneath the continents: probing the depths of geology. Annu. Rev. Earth Planet. Sci. 24, 385-432

Silver, P.G., Chan, W.W., 1988. Implications for continental structure and evolution from seismic anisotropy. Nature 335, 34-39.

Silver, P.G., Chan, W.W., 1991. Shear wave splitting and subcontinental mantle deformation. J. Geophys. Res. 96 (B10), 16429-16454.

Silver, P.G., Kaneshima, S., 1993. Constraints on mantle anisotropy beneath Precambrian North America from a transportable teleseismic experiment. Geophys. Res. Lett. 20, $1127-1130$.

Silver, P.G., Savage, M., 1994. The interpretation of shear-wave splitting parameters in the presence of two anisotropic layers. Geophys. J. Int. 119, 949-963.

Silver, P.G., Gao, S.S., Liu, K.H., 2001. Mantle deformation beneath southern Africa. Geophys. Res. Lett. 28, 2493-2496.

Simons, F.J., van der Hilst, R.D., 2003. Seismic and mechanical anisotropy and the past and present deformation of the Australian lithosphere. Earth Planet. Sci. Lett. 211, 271-286.

Snyder, D.B., Bostock, M.G., Lockhart, G.D., 2003. Two anisotropic layers in the Slave craton. Lithos 71, 529-539. doi:10.1016/j.lithos.2003.09.001.

Steinberger, B., OConnel, R.J., 1998. Advection of plumes in mantle flow: implications for hotspot motion, mantle viscosity and plume distribution. Geophys. J. Int. 132 (2), 412-434.

Tarduno, J.A., Duncan, R.A., Scholl, D.W., Cottrell, R.D., Steinberger, B., Thordarson, T. Kerr, B.C., Neal, C.R., Frey, F.A., Torii, M., Carvallo, C, 2003. The Emperor Seamounts: southward motion of the Hawaiian hotspot plume in earths mantle. Science 301 1064-1069.

Tommasi, A., 1998. Forward modeling of the development of seismic anisotropy in the upper mantle. Earth Planet. Sci. Lett. 160 (1-2), 1-13.

Turcotte, D.L., Schubert, G., 2002. Geodynamics. Cambridge University Press, Cambridge.

Vauchez, A., Nicolas, A., 1991. Mountain building: strike parallel motion and mantle anisotropy. Tectonophysics 185, 183-201.

Vauchez, A., Barruol, G., Nicolas, A., 1999. Comment on "SKS splitting beneath rift zones" by Gao et al., 1997. J. Geophys. Res. 104, 10787-10789.

Vecsey, L., Plomerová, J., Kozlovskaya, E., Babuska, V., 2007. Shear wave splitting as a diagnostic of variable anisotropic structure of the upper mantle beneath central Fennoscandia. Tectonophysics 438, 57-77.

Vecsey, L., Plomerová, J., Babuska, V., 2008. Shear-wave splitting measurements - problems and solutions. Tectonophysics 462, 178-196.

Vinnik, L.P., Kosarev, G.L., Makeyeva, L.I., 1984. Anisotropiya litosfery po nablyudeniyam voln SKS and SKKS. Dokl. Akad. Nauk UzSSR 278, 1335-1339.

Vinnik, L.P., Green, R.W.E., Nicolaysen, L.O., 1996. Seismic constraints on dynamics of the mantle of the Kaapvaal craton. Phys. Earth Planet. Inter. 95, 139-151.

Walker, K.T., Bokelmann, G.H.R., Klemperer, S.L., 2001. Shear-wave splitting to tes mantle deformation models around Hawaii. Geophys. Res. Lett. 28, 4319-4322.

Walker, K.T., Nyblade, A.A., Bokelmann, G.H.R., Klemperer, S.L., Owens, T.J., 2004. On the relationship between extension and anisotropy: constraints from shear wave splitting across the East African Plateau. J. Geophys. Res. 109, B0802. doi:10.1029/ 2003JB002866.

Walker, K.T., Bokelmann, G.H.R., Klemperer, S.L., Bock, G., 2005. Shear-wave splitting around the Eifel hotspot: evidence for a mantle upwelling. Geophys. J. Int. 163 (3), 962-980.

Walther, M., Plenefisch, T., Rümpker, G., 2007. Automated analysis of SKS shear-wave splitting for regional seismic networks. EGU Geoph. Res. Abstracts, vol. 9, p. 07475 (SRef-ID: 1607-7962/gra/EGU2007-A-07475).

Wiejacz, P., 2001. Shear wave splitting across Tornquist-Teisseyre zone in Poland. J. Balk. Geophys. Soc. 4 (4), 91-100.

Wüstefeld, A., 2007, Methods and Applications of Shear-Wave-Splitting: The East European Craton, PhD thesis, Univ. de Montpellier, France. http://www.gm.univmontp2.fr/splitting/.

Wüstefeld, A., Bokelmann, G., 2007. Null detection in shear-wave splitting measurements. Bull. Seismol. Soc. Am. 97 (4), 1204-1211.

Wüstefeld, A., Bokelmann, G., Zaroli, C., Barruol, G., 2008. SplitLab: a shear-wave splitting environment in Matlab. Comput. Geosci. 34 (5), 515-528.

Wüstefeld, A., Bokelmann, C., Barruol, G., Montagner, J.-P., submitted for publication, Identifying global seismic anisotropy patterns by correlating shear-wave splitting and surface waves data. Phys. Earth Planet Int.

Wylegalla, K., Bock, G., Gossler, J., Hanka, W., TOR-Working-Group, 1999. Anisotropy across the Sorgenfrei-Tornquist Zone from shear wave splitting. Tectonophysics 314, 335-350.

Zhang, L., Wu, J., Hao, T., Wang, J., 2006. Automatic lineament extraction from potentialfield images using the Radon transform and gradient calculation. Geophysics 71 (3) $\mathrm{J} 31-\mathrm{J} 40$.

Ziegler, P.A., 1990, Geological Atlas of Western and Central Europe, Shell Internationale Petroleum Maatschappij B.V./Geological Society of London/Elsevier.

Zielhuis, A., Nolet, G., 1994. Shear-wave velocity in the upper mantle beneath central Europe. Geophys. J. Int. 117, 695-715.

Zonenshain, L.P., Kuzmin, M.I., Natapov, L.M., Page, B.M. (Eds.), 1990. Geology of the USSR: A Plate-Tectonic Synthesis, vol. 21. AGU. 